This is the accepted version of the manuscript

\title{
Evaluation of Firefighter Leadership Trainings
}

\author{
published in the International Journal of Emergency Services
} and available via https://doi.org/10.1108/IJES-03-2018-0020.

Please use the following reference for this article:

Schulte, N. \& Thielsch, M. T. (2019). Evaluation of firefighter leadership trainings. International Journal of Emergency Services, 8 (1), 34-49. doi: 10.1108/IJES-03-2018-0020 


\title{
Evaluation of Firefighter Leadership Trainings
}

\begin{abstract}
Purpose

The training of highly skilled officers in rescue forces is essential for success and performance of fire brigades in their daily work. The purpose of this paper is to develop a validated instrument assessing the quality of leadership trainings in firefighter education.
\end{abstract}

\section{Design/methodology/approach}

In Study 1, relevant factors of teaching quality in this specific context are established using semi-structured interviews ( $\mathrm{n}=5$ trainer, $\mathrm{n}=59$ trainees), and a pool of corresponding survey items is tested in a pilot sample ( $n=7$ trainer, $n=26$ trainees). In Study 2 ( $n=263$ trainees), we select best-fitting items and explore the structure of latent variables via exploratory factor analyses. Study $3(n=45$ trainer, $n=380$ trainees) tests this structure by means of confirmatory analyses and validates the questionnaire using scales from other evaluation instruments for higher education.

\section{Findings}

Analyses resulted in a six-dimensional questionnaire reflecting relevant training processes and outcomes. Results suggest that the newly created Feedback Instrument for Rescue forces Education (FIRE) meets all relevant psychometric quality criteria.

\section{Originality/value}

By examining critical factors of training quality, we enhance the understanding of critical processes in programs for rescue forces education. The developed questionnaire provides trainers and educational institutions with a validated tool to measure these relevant processes and the desired training outcomes. Therefore, the FIRE scales can contribute to an ongoing improvement of rescue forces trainings.

Key words: Evaluation, vocational training evaluation, firefighter, fire service, rescue forces, questionnaire 


\section{Introduction}

Leadership positions in fire departments require a wide range of skills to handle challenging operating conditions safely. Before they take on these high responsibility jobs, prospective commanding officers are provided with special training. The quality of these trainings is not only important for future subordinates, who depend on their leaders in high risk situations, but it is also particularly important to the public. To consistently ensure that commanding officers are being offered high-quality courses, these trainings should be evaluated periodically, where evaluation is defined as a systematic investigation of a program's worth or merit that is derived from comprehensible, empirical qualitative and/or quantitative data (Beywl, 2003). However, to our knowledge, there is currently no such instrument for reliably and validly collecting data on trainings for firefighters. To bridge this gap, the Feedback Instrument for Rescue forces Education (FIRE; in German "FeedbackInstrument zur Rettungskräfte-Entwicklung”) was developed in a series of three studies: In Study 1, we conducted interviews with trainers and participants to establish factors of excellent teaching in the context of the aforementioned trainings. Based on this, we created a set of evaluation items. In Study 2, after testing for comprehensibility, relevance, and completeness, we performed an exploratory factor analysis (EFA) to reveal the underlying structure of factors that determine the quality of firefighter leadership trainings. Accordingly, we selected items which measure these factors best. Building on these results, Study 3 was supposed to validate this factor structure by means of confirmatory factor analyses (CFA) and to assess the construct validity of the extracted scales (e.g. whether the questionnaire captured the constructs it was hypothesized to cover). Agreement of trainers and trainees was assessed with a trainer's version of the questionnaire developed for this investigation.

\subsection{Structure of Trainings for Leadership Positions within the German Fire Service System}

Our studies were conducted in cooperation with the Institut der Feuerwehr NordrheinWestfalen (State Fire Service Institute North Rhine-Westphalia, IdF NRW), which is the largest of the 16 German state-run academies for fire service forces. At the IdF NRW approximately 16,000 firefighters and members of crisis committees receive trainings for all types of leadership positions in fire service every year. Within the current set of studies, we focused on trainings for group and platoon leaders, the two most prevalent training types for incident commanders. In Germany, a group leader has command over up to eight firefighters, i.e. the entire crew of a single vehicle like a pumper (Feuerwehrdienstvorschrift (FwDV) 3 [German Fire Service regulation 3], 2008). A platoon typically consists of a command car, the engines, and a ladder truck. A platoon leader supervises up to 21 firefighters (FwDV 3, 2008).

In professional fire departments ${ }^{1}$, firefighters are provided with training for leadership positions after working several years as crew members or directly after graduating from university. Voluntary fire departments dispatch participants based on their experience and the needs of the department. Depending on the intended position (group vs. platoon leader) and background (professional vs. volunteer fire department), the duration of the tactical trainings

\footnotetext{
${ }^{1}$ The German fire service system is organized on a voluntary basis with firefighters having other regular jobs and being alarmed on demand. Only larger cities or large companies employ full time firefighters.
} 
ranges from two to eight weeks, supplemented with a theoretical module (e.g. law) with a length of up to two years. The curriculum consists of different modules on various topics, such as general leadership techniques, leadership in chemical, biological, radiological or nuclear emergencies, and legal regulations, and there is a train-the-trainers module for instructing firefighters that rank lower ${ }^{2}$ in the organizational hierarchy (AG-BIII, 2007; AGFIII, 2005; AG-F IV, 2007). The content and complexity of these modules vary according to the aspired position.

Over the course of the trainings, a wide variety of teaching methods are used. While some content is taught in lectures, other parts comprise map exercises, group work with presentations, and independent (home) work. The skills acquired during these theory-driven lessons are applied in several mission simulations. On special training grounds, many facilities such as apartment buildings, a hospital, and laboratories set the scene for realistic mission exercises and leadership tasks (IdF NRW, 2012; IdF NRW, 2013).

\subsection{Common Concepts for Program Evaluation}

To assess the quality of the applied training concepts accurately, and to identify potential for further improvements, a proper evaluation system is needed. When measuring training outcomes, four steps are commonly distinguished: reaction, learning, behavior, and results (Kirkpatrick, 1979). Reaction is defined as how well the participants liked the evaluated training. The favorable reaction of trainees is an important precondition for learning processes (Blanchard and Thacker 2010; Kirkpatrick, 1998), as it promotes attention and motivation which are crucial cognitive processes for effective social learning (Bandura, 1977). On the second level, learning describes the degree to which principles, facts and techniques are understood by the trainees (Kirkpatrick, 1979). In a third step, changes in the participants' behavior on the job are determined. Finally, one can aim for measuring consequences for organizational results, e.g., increases in service quality or a reduction of costs (Kirkpatrick, 1979). Despite intensive literature research, we were not able to find measurement instruments for any of the above described evaluation stages for trainings of firefighters. Kirkpatrick (1979) suggests evaluating a program on higher levels only after it has been shown to be successful on lower levels. We therefore aim to develop a questionnaire that covers Kirkpatrick's (1979) first two steps of evaluation (reaction and learning).

Trainees' reactions are commonly assessed by means of standardized questionnaires (Blanchard and Thacker, 2010). Two types can be distinguished here: affective and utility questionnaires. "An affective questionnaire measures general feelings about training ('I found this training enjoyable'), whereas the utility questionnaire reflects beliefs about the value of training ('This training was of practical value')" (Blanchard and Thacker, 2010, pp. 333 f.). Here, we use the latter type as it is more conducive to identify indications for change.

On level two, the use of tests with a pre-post comparison in a control group design is recommended (Kirkpatrick, 1979). Other methods to measure the (subjective) learning success are self-ratings of participants, trainers or external raters (Holling, 1999). This approach is applied here to supplement existing exams trainees have to take at the beginning, in the middle, and/or at the end of their training.

\footnotetext{
${ }^{2}$ In Germany, regular crew members and squad leaders (a squad consists of two or three men or women) are trained on municipal or city level. Only trainings for higher positions are offered by state-run academies.
} 
A second classification of evaluation methods is the separation between process and outcome evaluation (Blanchard and Thacker, 2010). As processes are only covered on level one of the Kirkpatrick model, level one is essential for identifying parts that might have gone wrong. In identifying such areas, the trainers derive benefits from the evaluation and the quality of the training programs can be improved. Outcome measures provide important information on whether the training goals are achieved or not.

Therefore, the aim of the presented studies is to develop an evaluation questionnaire which allows trainers and training facilities to assess the quality of their trainings reliably and validly and to identify potential areas of further improvements.

\section{Study 1}

As a first step towards the development of a questionnaire, we first had to determine the critical factors of successful teaching in firefighter trainings.

\subsection{Method}

We conducted semi-structured face-to-face interviews with $n=5$ trainers and $n=3$ trainees at IdF NRW. Additionally, we administered paper-based interviews with the same questions to $n=56$ trainees. All participants were male, ranging from 23 to 56 years old $(M=$ $34.97, S D=7.9)$. They were instructed to remember prior leadership trainings and to state in detail the main characteristics of good teaching in the context of firefighter and rescue forces education. Additionally, they were asked to describe good trainers, good trainees, necessary context conditions, and potential bias variables that, in their opinion, may influence how trainees judge the quality of trainings (but do not actually influence the training quality itself; Marsh and Roche, 1997; Spiel, 2001). Participation took about 15 to 20 minutes and was voluntary, anonymous, and without any compensation.

\subsection{Results and Discussion}

Participants made 330 statements on characteristics of good teaching. Those were clustered in sub-categories via content analysis (Mayring, 2000) by two independent and trained observers. In the same manner, the aspects of a good trainer (209 statements), a good trainee (132 statements), good context conditions (158 statements), and potential biases (46 statements) were categorized (see Table A1 in the OSF material at osf.io/m39ug). This served as a basis for the subsequent generation of items, which were directly derived from the categorization scheme or, if applicable in the firefighting context, from other existing teaching evaluation instruments.

In a second step, we piloted the resulting list of 116 items to assess their comprehensibility and relevance (all items are available from the corresponding author upon request). Additionally, participants were asked whether the presented items covered all relevant aspects that affect the quality of leadership trainings in the context of firefighter and rescue forces education. The pilot sample consisted of $n=7$ trainers (male: 6; age: 27 to 45 years $M=38.9, S D=6.0$ ) and $n=26$ trainees (male: 25 ; age: 21 to 43 years $M=30.5, S D=$ 6.9) at IdF NRW. The items were rated as understandable, appropriate and exhaustive. Thus, it appears legitimate to conclude that from the perspective of trainers and trainees, the item list covered all important aspects of trainings for leadership positions at fire departments. This indicates high content and face validity of the constructed item set. Furthermore, items 
could be separated in two groups: First, 65 questions regarded general aspects of firefighter education that are applicable in nearly every possible training course (Table A2 of the OSF material at osf.io/m39ug). Second, 51 questions included very specific teaching methods used at IdF NRW (such as different forms of mission simulations, homework or group tasks) that are not applied in every step of the leadership trainings as well as items regarding potential bias factors. In the following two studies, we will focus our analyses on the items that were generally applicable.

\section{Study 2}

The aim of the second study was to explore factors that are most relevant for a general training's quality and to reduce the item set. For this purpose, we employed a quantitative empirical approach using exploratory factor analysis (EFAs), an adequate method to narrow down data from a large item pool to a smaller set of underlying latent factors (see Costello and Osborne, 2005). Additionally, EFAs allow for the inclusion and exclusion of items based on their ability to capture these factors.

\subsection{Method}

\subsubsection{Sample}

A total of 263 trainees from eleven group- and platoon-leader courses completed the evaluation, resulting in a response rate of $97 \%$. Data from 20 participants were excluded from further analyses as they either did not agree with the use of their data $(n=10)$, did not respond to more than $10 \%$ of the items $(n=7)$, or had a monotonous or unrealistic answering style $(n$ $=3$ ). The final sample consisted of 243 participants $(96 \%$ male, which represents a typical proportion in these trainings) ranging from 21 to 55 years old $(M=31.8, S D=6.5)$. The mean job experience was $13.8(S D=8.2)$ years with on average $9(S D=15.5)$ emergency incidents per month. In the sample, $14 \%$ worked at professional fire departments, $70 \%$ at volunteer departments and $16 \%$ stated to be engaged in both. Participants took part voluntarily and on an anonymous basis without any compensation.

\subsubsection{Measures and Procedure}

Participants filled out the paper and pencil questionnaires at the end of the trainings but before a final exam. We collected data from 44 items measuring processes and 21 items measuring outcomes of the trainings (Table A2 of the OSF material at osf.io/m39ug). The items were rated on a seven-point Likert scale $(1=$ strongly disagree, $7=$ strongly agree $)$. Besides these, other items were part of the questionnaire but not analyzed in this context as they measured bias variables, provided first validation estimates or asked for special teaching methods at IdF which are not part of the core evaluation questionnaire presented here.

\subsubsection{Statistical Analyses}

All data analyses were performed with $\mathrm{R}$ (R Core Team, 2016) using the packages e1071 (Meyer at al., 2015), psych (Revelle, 2016), and lavaan (Rosseel, 2012). We calculated descriptive statistics (means, standard deviations, response rate, skewness, and excess) as well as Pearson item inter-correlations for the purpose of item selection, i.e., to avoid items not capable of describing differences in course quality adequately and independently from the information generated by other items. With the selected items, we conducted exploratory 
factor analyses (principal component analyses). Items reflecting the behavior of trainers were not excluded for skewness, excess, means or standard deviations to make sure there were enough items for this scale in this step. To maximize the acquired information per factor while accounting for the expectable dependencies between process and outcome factors, we conducted one EFA for process and one for outcome variables, each with varimax rotation.

\subsection{Results and Discussion}

\subsubsection{Item Selection}

Items had to be removed if they (a) were answered by less than $95 \%$ of the participants (none of the items relevant for this study met this criterion), (b) had an absolute skewness value of $>2$ (none of the relevant items) or an absolute excess value of $>7$ (none of the relevant items), (c) showed item inter-correlations $>.75$ (five items), or (d) had a mean $\geq 6$ and a standard deviation of $\leq 1$ (three items). Additionally, one item was excluded due to its limited relevance in combination with an unfavorable answer distribution. The final item set included in the exploratory factor analyses comprised 39 process and 17 outcome items.

\subsubsection{Exploratory Factor Analyses for Process Items}

The scree test (Cattell, 1966) suggested that two or four factors should be extracted, the parallel analysis (Horn, 1965) suggested this should be four factors. Therefore and because of content-related deliberations, four factors were extracted. Based on the loading patterns, we excluded 23 items as they showed the lowest factor loading on the respective factors. For the remaining items, we conducted discriminatory power analyses which did not lead to additional exclusions. To further reduce the number of items, we calculated reliabilities (raw alphas) if an item was dropped. In this step, two items were excluded due to dropped $\alpha$ value in combination with content-related reasons and one item was excluded based on its dropped $\alpha$ value exclusively. For detailed information on all items and the corresponding reasons for exclusion, see Table A2 in the OSF material at osf.io/m39ug; for the factor matrix, see Table A3 in the OSF material.

\subsubsection{Exploratory Factor Analyses for Outcome Items}

EFAs were performed the same way for outcome items as they were for process items. The scree test (Cattell, 1966) suggested one factor, the parallel analysis (Horn, 1965) two factors. We decided to extract two factors. The discriminatory power was sufficient for all tested items, and estimates for $\alpha$ if the item was dropped did not differentiate between the items.

Five items were excluded as they exhibited high cross-loadings on both factors. An additional four items were excluded with regard to the content (e.g. very specific focus) and the loading patterns. Item-specific reasons for exclusion are presented in Table A2, and relevant item parameters are shown in Table A4 of the OSF material at osf.io/m39ug.

\subsubsection{Extracted Scales and Their Interpretation}

The final questionnaire measures the four process factors trainers' behavior, structure, overextension, and group as well as the two outcomes factors self-rated competence and transfer. The first scale of the version tested here (trainers' behavior) is supposed to reflect the degree to which the trainers motivate participants, deliver their lessons concisely and give useful feedback. Moreover, it asks whether trainers are interested in trainees' learning success. 
The trainer scale consists of four items. Clarity of structure during the whole training is assessed with the three-item structure scale. The overextension scale (three items) covers task difficulty, speed of impartation, and the number of topics addressed. As the last process variable, the group scale deals with the active participation and mutual social support of trainees (three items). Competence acquisition was designed to cover five different learning areas associated with action regulation in emergency situations. Finally, the transfer scale asks for self-rated ability to use the acquired knowledge appropriately on the job (three items). Items of the final questionnaire are presented in Table 1; values for reliability in terms of internal consistency in Table 2.

Table 1

\begin{tabular}{cll} 
Final FIRE Items & \\
\hline $\begin{array}{c}\text { Item } \\
\text { no. }\end{array}$ & Dimension & \\
\hline 1. & trainer & The trainers condensed difficult topics concisely. \\
2. & trainer & I think the trainers gave useful feedback. \\
3. & trainer & The trainers motivated me to participate actively in the course. \\
4. & trainer & I think the trainers were interested in the learning success of the participants. \\
5. & overextension & I was overexerted by the amount of subject matter. (reversed) \\
6. & overextension & The speed of impartation was too high. (reversed) \\
7. & overextension & The course content was too difficult to me. (reversed) \\
8. & structure & I think the course was well-structured. \\
9. & structure & I was always able to follow the structure of the course. \\
10. & structure & I think the course gave a good overview of the subject area. \\
11. & group & The other trainees participated actively. \\
12. & group & The participants supported each other. \\
13. & group & I think there was a strong cohesion within the course. \\
14. & competence & After this training, I can identify dangerous situations earlier. \\
15. & competence & After the training, it is easier to make decisions in critical situations. \\
16. & competence & After this training, I know my personal limitations better than before. \\
17. & competence & After this training, I dare to keep calm in stressful situations better. \\
18. & competence & The training enabled me to give more specific and clearer assignments. \\
19. & transfer & I feel prepared very well for my next mission as a leader. \\
20. & transfer & By participating in the field trainings, I gained the necessary self-assurance \\
& & for leading a mission. \\
21. & transfer & I can use the acquired knowledge on the job. \\
\hline Note. & Trainer &
\end{tabular}

Note. Trainer $=$ Trainers' behavior, competence $=$ competence acquisition. Note that high scores one overextension items indicate high levels of overextension and therefore low trainer performance. Reversal of the item scores for these items is therefore recommended. See scoring instruction in the online supplement for details. 
Taken together, Study 2 resulted in a short questionnaire measuring six scales with 21 items. The scales correspond in part directly to the variables of successful teaching in firefighter trainings identified in Study 1. The scales trainer and group were identified in both investigations. We assume the factor trainees was merged in the group scale as both constructs have a definitional overlap. In contrast, the broad trainer category derived from Study 1 turned out to be empirically divisible into general trainer behavior and the training's structure. Likewise, teaching success (as identified in study 1, see Table A1) can be divided into competence acquisition and transfer. For printable FIRE versions (English and German) as well as for scoring instructions, see the OSF material at osf.io/m39ug.

Table 2

Reliability coefficients and measurement model tests for all FIRE scales

\begin{tabular}{|c|c|c|c|c|c|c|c|}
\hline \multirow[b]{2}{*}{ Scale } & \multicolumn{2}{|c|}{ Study 2} & \multicolumn{5}{|c|}{ Study 3} \\
\hline & Cronbach's $\alpha$ & $\omega_{\mathrm{H}}$ & Cronbach's $\alpha$ & $\omega_{\mathrm{H}}$ & $\Delta \chi^{2}$ & $d f$ & $p$ \\
\hline Trainers' behavior & .83 & .83 & .73 & .78 & 156.50 & 4 & $<.001$ \\
\hline Structure & .83 & .83 & .80 & .81 & 89.80 & 3 & $<.001$ \\
\hline Overextension & .86 & .87 & .86 & .86 & 22.44 & 3 & $<.001$ \\
\hline Group & .74 & .76 & .79 & .81 & 138.04 & 3 & $<.001$ \\
\hline Competence & .85 & .85 & .82 & .82 & 127.24 & 5 & $<.001$ \\
\hline Transfer & .78 & .80 & .75 & .76 & 73.83 & 3 & $<.001$ \\
\hline
\end{tabular}

Note. $N_{\text {Study } 1}=243, N_{\text {Study } 2}=382 . \chi^{2}$-difference tests compare essentially tau-equivalent with congeneric measurement models.

\section{Study 3}

The aim of the third study was to cross-validate the questionnaire's internal structure proposed in Study 2 by means of confirmatory factor analyses (CFA's). Additionally, we collected information on the construct validity of the instrument and investigated the agreement of trainers and trainees.

\subsection{Method}

\subsubsection{Sample}

All firefighters who received training as group or platoon leaders at IdF NRW in the first quarter of 2017 were asked to participate. The intended sample size was $N=400$ based on the recommendation for CFAs with three indicator variables per factor and loadings of .6 (Gagne and Hancock, 2006). A power analysis for correlative validity measures showed that this would be sufficient even for small effects $(|\rho|=0.12$, power $=.8)$. The sampling procedures yielded a total sample size of 382 trainees (from 18 different courses). The response rate was $88 \%$. Two participants were excluded from analyses due to missing values on all major variables of the study and another one because of straight-lining. The ages of the participants were between 20 and 55 years $(M=33.3, S D=6.9)$, and $95 \%$ of them were male (a representative number in these kinds of trainings). The mean job experience of voluntary firefighters was $14.42(S D=6.6)$ years with on average $6.35(S D=12.0)$ emergency incidents 
per month. The mean job experience of professional firefighters was $9.35(S D=7.3)$ years with $24.62(S D=23.9)$ emergency incidents per month. In the sample, 54\% worked at professional fire departments, $25 \%$ at volunteer departments and $21 \%$ stated to be engaged in both. Additionally, we collected 45 evaluations from the trainers' perspective. ${ }^{3}$ All participants took part voluntarily and anonymously without any compensation.

\subsubsection{Measures}

In addition to the FIRE items (German version; see Table A5 in the OSF material at osf.io/m39ug), scales from other well-established evaluation instruments for college lectures were used for the validation of individual FIRE scales. Items measuring the overall satisfaction served as a criterion (for details, see OSF material at osf.io/m39ug). Bias variables formed a third group of measures. Together with these measurements, data for the construction and validation of additional, more specific scales not pertinent to the present paper were collected. Please refer to the corresponding author for a detailed list of items used here. Unless specified differently, participants indicated their agreement with the statements on a seven-point scale (from $1=$ strongly disagree to $7=$ strongly agree) with an unanswerable option.

\subsubsection{Scales Corresponding to Individual FIRE Scales}

We used scales from other validated evaluation questionnaires as convergent criteria for specific FIRE scales, primarily from two German evaluation instruments for higher education (HILVE, Rindermann, 2001 and TRIL, Gläßer et al., 2002). None of the established evaluation scales cover the group of trainees with an according scale. Therefore, we asked about group-related behaviors with three self-developed items (e.g. "On how many evenings of the course did you spend at least two hours sitting together?"). For a detailed description, including reliabilities and sample items of each scale employed here, we refer the reader to the supplemental material.

\subsubsection{Bias Variables}

We used the following single item measures for bias variables: "I felt very well prepared for this training." (preparation prior to the training), "The amount of time I spent with the training was appropriate for me." (time expenditure), "The group size was adequate." (group size), "I was able to fully concentrate on the training." (concentration), "I feel very well prepared for the exam." (preparedness for exams), "I am proud to be trained for this kind of leadership position (group leader/platoon leader)." (proud of the participation in a leadership training). Mood was measured with a five-point equidistant smiley scale (Jäger, 2004).

\subsubsection{Valuation by the Trainers}

The trainers' perspective was captured by a specially developed version of the FIRE questionnaire. Out of 21 items, 15 were adapted slightly (e.g., "After this training, the

\footnotetext{
${ }^{3}$ Trainers were between 28 and 67 years old $(M=39, S D=7.58)$. As it is representative for trainers at IdF, $91 \%$ were male. Their mean job experience at voluntary fire departments was $M=17.09$ years $(S D=9.4)$ and at professional fire departments $M=8.87$ years $(S D=7.44)$. Trainers reported to have $M=2.54$ emergency incidents per month $(S D=2.2)$ at voluntary fire departments and $M=18.34(S D=27.21 ; M d n=5.5)$ incidents at professional fire departments.
} 
participants can identify dangerous situations earlier." instead of "After this training, I can identify dangerous situations earlier."). 


\subsubsection{Procedure}

All participants completed the evaluation questionnaire at the end of the training but before the exam, if there was one. The questionnaires were handed out by the trainers and were returned to them in a sealed envelope. Participants responded voluntarily and anonymously. Each trainer was requested to complete the trainer version of the questionnaire. Trainers were not assured of anonymity, as the study design requested that their questionnaires matched with the questionnaires of participants who took their course.

\subsubsection{Statistical Analysis}

The paper-pencil questionnaire was built and scanned with EvaSys (version 7.0). All data analyses were performed with $\mathrm{R}$ (R Core Team, 2016; version 3.3.2) using the packages psych (Revelle, 2016; 1.6.12), multilevel (Bliese, 2016; version 2.6), lavaan (Rosseel, 2012; version 0.5-22), semPlot (Epskamp, 2014; version 1.0.1), semTools (semTools Contributors, 2016; version 0.4-14), and metafor (Viechtbauer, 2010; version 1.9-9). A first model was fitted for process (trainers' behavior, structure, overextension, and group) and a second one for outcome scales (competence and transfer). For the associations of FIRE subscales and validity criterions, correlation coefficients were calculated. To determine the agreement of trainers and trainees, a meta analytic approach was applied. Based on means of trainers and trainees per course, we calculated standardized mean differences (Hedges' $g$ ) with pooled standard deviations for each FIRE scale. This procedure also considered the varying sample variance, which was caused by the course-specific sample size in both the trainee and the trainer group. Since the agreement depends highly on the trainer's ability to judge his or her work correctly, random effects models with restricted maximum likelihood estimation were used.

\subsection{Results and Discussion}

\subsubsection{Descriptive Statistics and Reliability}

Means, standard deviations, intra class correlations and correlations for all measures used in the current study are presented in Table A7 of the OSF material at osf.io/m39ug. Table A8 (OSF material) reports overall evaluation results from both, study 2 and 3 . The reliability estimates for all FIRE scales are reported in Table 2. A very common measure of reliability is Cronbach's $\alpha$. Yet, for each scale, $\omega_{\mathrm{H}}$ (McDonald, 1999) is the more appropriate reliability measure, as congeneric measurement models fit better than essentially tauequivalent models (for $\chi^{2}$-difference tests results see the last three columns of Table 2). Applying the reliability standards for the assessment of learning success and program evaluation (Evers, 2001), the reliability of all FIRE scales can be judged as sufficient (trainers' behavior and transfer) or good (structure, overextension, group, and competence scale). Results based on the data of Study 3 confirm the estimates based on Study 2. Only the reliability of trainers' behavior was considerably lower in Study 3 but still acceptable. Compared with other German teaching evaluation instruments, FIRE scales reach equal (e.g., compared with HILVE teaching competence scale, TRIL structure scale) or considerably higher levels of internal consistency (e.g. compared with HILVE overextension). 


\subsubsection{Factorial Structure}

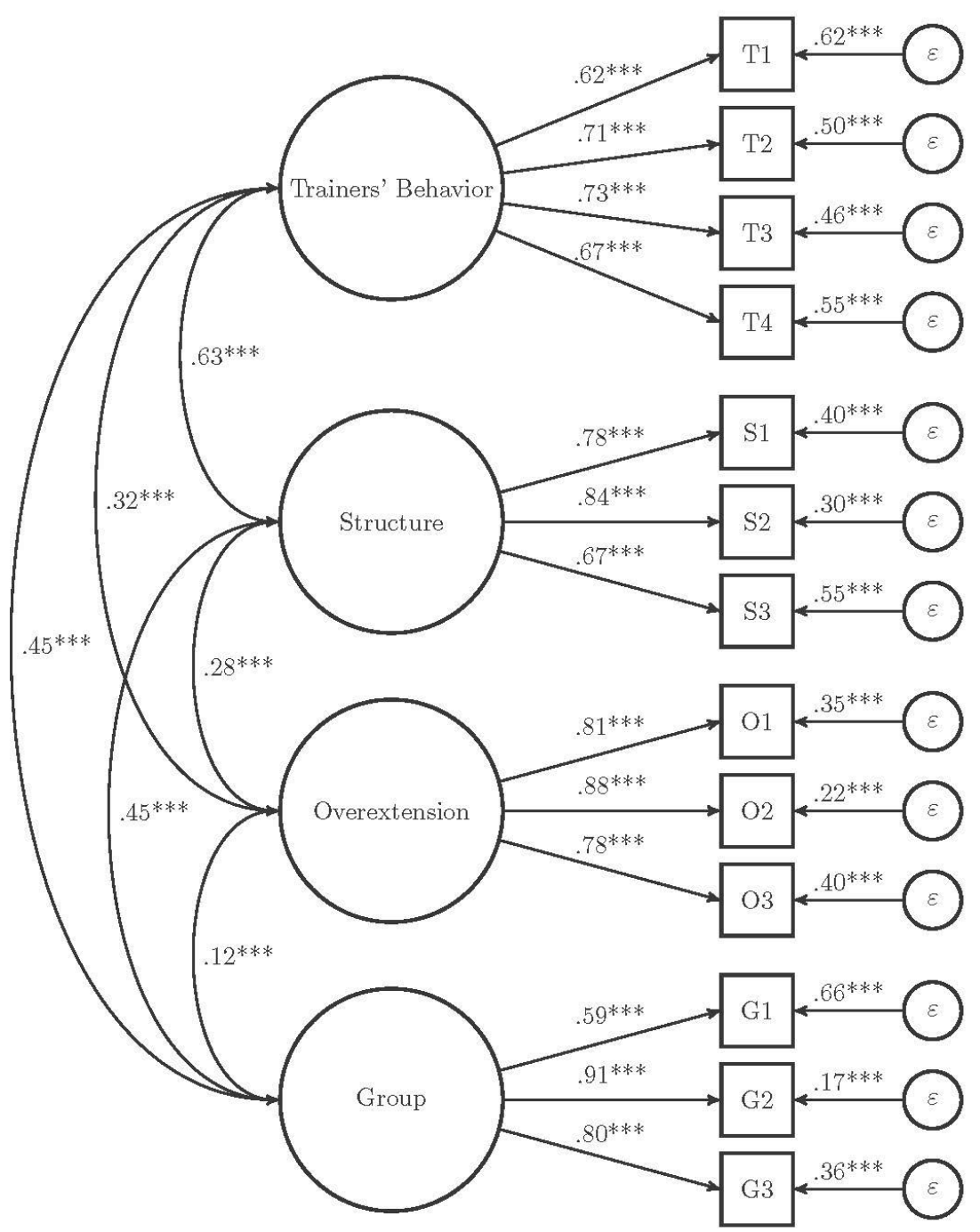

Figure 1. Results of confirmatory factor analysis for process scales, standardized coefficients. $* p<.05 . * * . p<.01 . * * * p<.001$.

To replicate the factor structures found in Study 2, confirmatory factor analyses (CFAs) were conducted testing two models. The first model consisted of the four process factors trainers' behavior, structure, overextension and group. According to the criteria laid out by Schermelleh-Engel et al. (2003), the model displayed an acceptable fit (CFI = .96, RMSEA $=.06[.05, .08], \mathrm{SRMR}=.06$. Only the TLI value of .94 did not meet the regular fit criteria. The $\chi^{2}$-test was significant $\left(\chi^{2}(59)=146.37, p<.001\right)$ which is typical for large sample sizes. However, relative to the degrees of freedom, the $\chi^{2}$-value was acceptable $\left(\chi^{2} / d f\right.$ $=2.48$ ). Figure 1 shows all path coefficients for this model. Overall, results support the specified model.

The second model supposed that outcome measures build two factors (Competence and Transfer). This model yielded a good fit based on the SRMR of .04 and an acceptable fit 
based on a CFI of .95. Two fit indices did not reach an acceptable level (RMSEA $=.09$ [.07, $.11]$, TLI $=.93)$. The $\chi^{2}$-test was significant $\left(\chi^{2}(19)=74.80, p<.001\right)$ and the $\chi^{2} / d f$ ratio was not acceptable $\left(\chi^{2} / d f=3.94\right)$. Modification indices for this initial model indicated that a correlation between the first and the second item of the Competence factor should be added to the model. Item one of this scale asks about trainees' abilities to identify critical situations earlier, and item two asks about trainees' abilities to make decisions in such situations. We consider this overlapping content as a reasonable theoretical explanation for the fact that both items covary beyond the degree that is explained by the extracted factor. Thus, we allowed the two items to covay in a new model. The fit indices of this new model are acceptable (TLI = $.96, \mathrm{RMSEA}=.07[.045, .09]$ to $\operatorname{good}(\mathrm{CFI}=.97$; SRMR $=.03)$. The $\chi^{2}$ test is still significant $\left(\chi^{2}(18)=48.386\right)$ but the $\chi^{2} / d f$ ratio is now acceptable $\left(\chi^{2} / d f=2.69\right)$. Fit indices and a $\chi^{2}$ difference test $\left(\chi^{2}(1)=26.41, p<.001\right)$ suggest the recent model, presented in Figure 2. Results provide support for a two-factor structure.

Thus, as the EFA of Study 2 suggested, the FIRE questionnaire measures four distinct process variables (trainers' behavior, structure, overextension, and group) as well as two different outcome variables (self-rated competence and transfer). The multidimensional structure of the questionnaire demonstrates that prospective firefighter leaders differentiate among several components of effective teaching. This also implicates the absence of large halo effects, i.e. responses are not simply a generalization from some subjective feelings, external influence or an idiosyncratic response mode influencing responses to all items (Marsh, 1987).

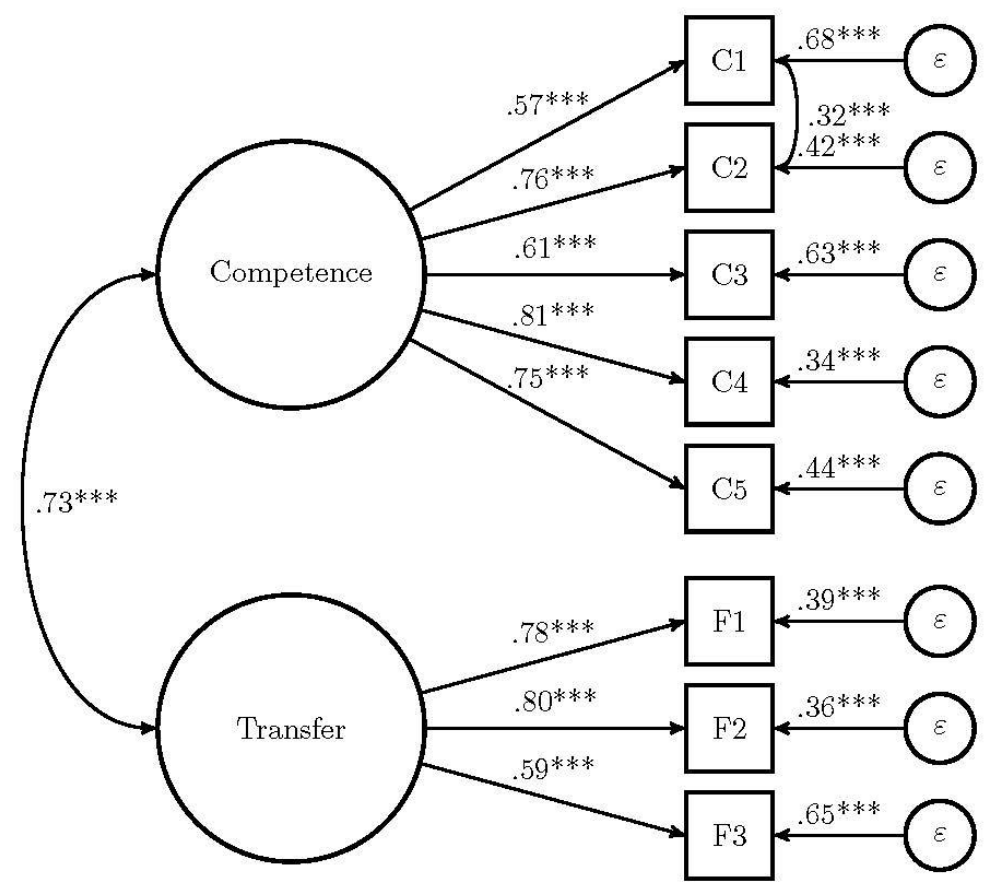

Figure 2. Results of confirmatory factor analysis for outcome scales, standardized coefficients. ${ }^{*} p<.05 . * * . p<.01 . * * * p<.001$. 


\subsubsection{Bias variables}

We tested for the influence of six bias variables which are presented as measures 17 to 22 in Table A7 in the OSF material at osf.io/m39ug. Based on Cohen's (1992) classification, the effect sizes can be judged as small to medium. Only time expenditure showed a large association with the overextension scale $(r=.43, p<.001)$, what might be seen as evidence for the validity of this scale because it can be assumed that participants who perceive the training as challenging need to spend more time with the course and the exam preparation than those who find it straightforward. Furthermore, results clearly contradict criticism on the meaningfulness of training evaluation results by denotations such as happiness sheets (Hölbling, 2007; also reported in Kirkpatrick, 1998). Even when neglecting the reciprocal association of mood and the assessment of training quality (i.e., mood might not only influence quality ratings but might also be a result of training quality), mood can only explain a small percentage of variance in the evaluation results.

\subsubsection{Association With Corresponding Scales of Existing Evaluation Instruments}

Results for scales of other established teaching evaluation instruments are presented as variables 7 to 10, 12, and 13 in Table A7 of the OSF material at osf.io/m39ug. All FIRE scales show large associations with their corresponding scales from other evaluation instruments (trainers' behavior and teaching competence (HILVE) $r=.67, p<.001$ and $r=$ $.59, p<.001$ for teachers' support (HILVE); $r=.66, p<.001$ for the structure scales of TRIL and FIRE; $r=.66, p<.001$ for overextension scales of HILVE and FIRE; $r=.50, p<.001$ between the competence scale (FIRE) and quantitative learning as well as $r=.55, p<.001$ for competence and qualitative learning (both HILVE II). Significant correlations of FIRE scales with validation scales measuring one of the other facets were also observed, but with consistently smaller effect sizes. The self-constructed group validation measure and the FIRE group scale were moderately associated with each other $(r=.36, p<.001)$. Note that the validation measure's low internal consistency of $\alpha=.57$ restricts the obtainable empirical correlation. Taken together, results show consistent positive associations for all FIRE scales with corresponding scales of other validated evaluation tools.

\subsubsection{Criterion Validity}

All FIRE scales show medium to large associations with trainees' overall satisfaction ( $r$ ranging from .31 to $.56, p<.001)$ and the school grade for the entire course ( $r$ ranging from .21 to $.43, p<.001$ ); see Table $\mathrm{A} 7$ in the OSF material at osf.io/m39ugfor detailed results. Thus, results support the valid prediction of both criteria investigated here.

\subsubsection{Agreement Between Trainers and Trainees}

To estimate the agreement between trainers and trainees, we applied random effects meta-analytic techniques with courses on study level. Effect sizes are Hedges' gs, which indicate the differences between the mean rating of all trainers and the mean rating of all participants from a specific course divided by the pooled standard deviation of both groups. For a detailed report on the results of the meta-analyses see Table A9 in the supplemental material. Negative gs are obtained if participant ratings are more positive than trainers' judgements. Results indicate that trainers do not judge themselves $(\hat{\theta}=-.14,95 \%$-CI [-.57, $.29])$, the structure $(\hat{\theta}=-.46,95 \%$-CI $[-.93, .01])$ or the group of participants $(\hat{\theta}=-.62,95 \%$ - 
CI [-1.26 .02]) consistently more positive or negative than trainees do. This does not necessarily imply that in each course trainers and trainees absolutely agree, but only that our results offer no evidence for general severity or leniency bias on the side of the trainers or trainees relative to each other. It should be stated, however, that power for these tests was low and missing evidence for differences should not be interpreted as a proof of agreement on these scales. On the other scales, differences are medium to large or large (Cohen, 1992). Trainees perceive the training as considerably less overexerting $(\hat{\theta}=-.91,95 \%$-CI $[-1.25$, $.58])$ and rated their own competence acquisition $(\hat{\theta}=-.63,95 \%$-CI $[-1.04,-.22])$ and transfer $(\hat{\theta}=-.66,95 \%$-CI $[-1.11,-.22])$ more positively. Trainers showed a severity tendency compared to the trainees. This tendency seems to be less pronounced on scales which can be easily influenced by themselves (trainer's behavior, structure). On scales that are stronger affected by participants' characteristics (overextension, group, competence, transfer), trainers showed a more pronounced severity tendency (or trainees a stronger leniency tendency respectively). Overall, the agreement is sufficiently high to assume a (at least to a certain degree) shared understanding of the content covered by the FIRE scales, but it is too low to rely on trainers' self-appraisals exclusively.

\section{General Discussion}

Given the enormous importance of leadership skills for officer-level firefighters, they must be trained to a very high quality. The present paper addresses the lack for an evaluation instrument for such trainings, resulting in a short and powerful tool for quality management in firefighter education. Altogether, evidence for several kinds of validity was collected. The exhaustive item construction based on qualitative analyses, especially results of the pilot described in Study 1, offered support for face and content validity: Participants explicitly stated the items covered all relevant aspects affecting the quality of trainings, and items were rated as appropriate and exhaustive. Subsequent item exclusions were carried out in close contact with subject-matter experts at IdF, where they affirmed face and content validity of the condensed items. Building on these results, the third study confirmed the proposed factor structure found in Study 2 using a completely different sample of trainees. Despite the moderate influence of some bias variables, Study 3 provides strong evidence for construct validity. Criterion validity was demonstrated for the prediction of participants' satisfaction and their overall course appraisal. Altogether, the FIRE questionnaire is highly capable of assessing rescue forces trainees' evaluations during leadership trainings. Covering the first two levels of Kirkpatricks (1979) evaluation framework, namely reaction and learning, trainers and responsible executives in firefighter education can get an impression about the success of their work using a short, time-efficient measure. Further, trainers can determine which areas to change, specifically with regard to the didactics used and the required level of exertion as well as by reviewing results on group behavior, perceived learning success, and transfer of knowledge.

The newly developed evaluation instrument offers several practical benefits. First, we provide an option to measure the quality of firefighter trainings economically, meeting all central psychometric standards. Implementing the instrument within a course does not require further skills and only adds 10 minutes. Evaluation should take place directly after the training and under controlled conditions like in a seminar room. Besides that, scoring procedures are 
very straightforward. Each item value ( 7 for the most and 1 for the least preferable answer option) is assigned to the corresponding scale. Then, averages are calculated on participant level (scale values) and these, in turn, are aggregated on course level. Applying regular survey software, data can be easily collected via mobile devices and analyzed electronically, leading to further time efficiency.

Even though the instrument was developed in cooperation with a firefighter academy, we made sure that items do not contain fire service-specific content but cover relevant aspects of rescue forces trainings in general. We assume that underlying principles of good teaching are comparable between fire service, ambulance service and other rescue forces. Beyond that, the items might be applicable for leadership trainings in other high-reliability contexts such as police agencies or the military. However, the scales have been validated only in the firefighter context so far. Thus, the transfer into other areas of application requires further validation studies. Results suggest that it would be worth the effort: The diverging judgements of trainers and trainees on several FIRE scales in Study 3 underline that evaluations by the trainees add information which cannot be obtained by simply asking trainers.

\subsection{Lessons Learned}

On a theoretical level, the present studies add to the understanding of good teaching in firefighter education and its evaluation. By confirming the proposed factorial structure, we demonstrated that the multidimensional nature of student evaluations, as has been pointed out for college lectures (Ghedin and Aquario, 2008; Marsh, 1987), also holds true in vocational training contexts in rescue services. Our factors correspond very well to established dimensions of evaluation instruments for college lectures: The Students' Evaluation of Educational Quality questionnaire (SEEQ; Marsh, 1984) - one of the most widely used and empirically tested tools - describes nine dimensions of which seven are also covered by FIRE scales. Namely, Learning, Group Interaction, and Workload/Difficulty are completely analogous. Additionally, Enthusiasm and Individual Rapport form the Trainers' Behavior scale, Organization and Breadth of Coverage together form the FIRE Structure scale. Only the dimensions Examination and Assignments are not covered by FIRE scales, as they are not considered core aspects of vocational trainings for rescue forces.

Further implications for the understanding of latent factors in the quality of vocational trainings can be derived from the intercorrelations of FIRE scales. A high intercorrelation and similar association patterns with other variables indicate a close relationship between the FIRE factors of trainers' behavior and structure. Both factors are tightly linked to trainers' actions. In contrast, overextension and group also depend on participant characteristics. These patterns are in line with the multifactorial model of course quality (Rindermann and Schofield, 2001), which classifies structure and several behavioral aspects of teaching activities as a combined trainer factor. High intercorrelations of acquired competence and transfer can be interpreted in two different ways: One possible explanation is that if a trainee learns something during a training at IdF, the likelihood of him/her being able to transfer the acquired competence into on the job behavior is high. This interpretation is supported by the fact that trainings have a clear vocational focus, and much time is spent with mission exercises. Alternatively, one may assume that trainees have limited abilities to predict transfer of acquired knowledge into their on-the-job behavior, and therefore trainees derive the appraisal of transfer from a single higher-level mental concept of perceived training success. 
However, contradicting this interpretation, confirmatory factor analysis clearly confirmed two latent factors, which explain response behavior. Additionally, trainees for leadership positions already have considerable professional experience as firefighters and are therefore experts in judging transferability of course contents. Thus, the chosen approach of basing the FIRE scales on a qualitative exploration of good teaching in the target area combined with a literature search, an explorative, and a confirmatory study has led to a sound evaluation instrument.

\subsection{Limitations and Future Research}

The FIRE scales were developed in close dialogue with the largest state-run academy for fire service forces in Germany; tested samples did not differ in any known way from the target population of trainees at German firefighter academies. Yet, empirical evidence for the validity of our scales has been collected in fire service context exclusively. Consequently, to use the scales in other contexts, there should at least be another expert rating on face and content validity for the planned context. Generally, experiences should be collected with the administration and interpretation of FIRE scales in other institutions and by evaluation coordinators not part of the development team in order to test its robustness in different contexts.

Users should also be aware of the fact that the questionnaire was developed for trainings that prepare for leadership positions in which the trainee will supervise up to 21 firefighters (one platoon). These positions require limited strategic competencies regarding the coordination of tactical units as a German fire service platoon consists of two teams and one squad. Therefore, FIRE scales presented here could be well applied in trainings for ranks that are associated with comparable tactical and strategical duties. Other ranks may require training aspects not covered by these scales. Thus, in currently ongoing studies, we test adaptions of the FIRE scales in trainings at a basic level as well as for higher, more strategic positions and crisis management groups.

Due to the low percentage of female respondents in our sample, we cannot draw any conclusions about potential gender effects in the response process. We were neither able to investigate potential effects of trainees' gender on their judgments nor whether male and female trainers are evaluated equally. However, our sample is representative for the population of fire service forces and trainers in this field. More woman working in the respective positions are a requirement for reliable investigations of these questions. Besides, investigations on other potentially relevant facets of response behavior in teaching evaluations in this context, such as survey mode or aspects of social exchange (see Thielsch, Forthmann \& Brinkmöller, 2018), might be worth investigating.

Furthermore, having a tool for the first levels of the Kirkpatrick model at hand, future research should address levels three and four (behavior and results). While the instrument introduced here relies on self-ratings of learning success, further studies should investigate their relationship with other data sources like exam results and performance in the field. In this context, larger data sets are required to investigate co-variation of both kinds of measures on the course level, as being able to explain between-course variance is of central importance in this context.

Finally, we need to point out that all of our studies used the German FIRE version. Future research should check the English version for appropriateness of the content in other 
fire service systems and test the English translation with the same procedures as described in Study 3 before use. Other language versions of the FIRE measures are highly welcome as well. 


\subsection{Conclusion}

This paper provides the first validated evaluation questionnaire for trainings of firefighters aspiring to leadership positions. The FIRE scales are ready for use and represent an economic, reliable and valid way to measure the quality of trainings for rescue forces. Providing trainers and executives in firefighter education and beyond with such a tool, we hope to contribute to the ongoing improvement of public emergency infrastructure.

\section{Acknowledgements}

The authors declare no conflict of interest.

The authors thank the IdF NRW, in particular Berthold Penkert, Thomas Löchteken, Yannick Ngatchou, Stephanie Vöge and Matthias Wegener for their support in conducting this research. Special thanks to Stephanie Babiel, who put a lot of effort in conducting Study 1 and 2, and Mona Beverborg for her contributions to Study 3. Also, the authors thank Celeste Brennecka, Guido Hertel, and Heinz Holling for their valuable suggestions.

\section{References}

AG-B III - LFV NRW, AGBF NRW, WFV NRW, \& IdF NRW (2007). Lernziele für die Ausbildung zum Gruppenführer in der Berufsfeuerwehr [Learning Objectives for the Training of Group Leaders in Professional Fire Departments]. Retrieved from http://www.idf.nrw.de/service/downloads/pdf/biii_lzk_2008.pdf.

AG-F III - LFV NRW, AGBF NRW, WFV NRW, \& IdF NRW (2005). GruppenführerAusbildung und Truppmann- / Truppführer- Aus- und Fortbildung der Freiwilligen Feuerwehren in Nordrhein-Westfalen [Group Leader Training and Troop Member/ Troop Leader Training for Voluntary Fire Departments in North Rhine-Westphalia]. Retrieved from http://www.idf.nrw.de/service/downloads/pdf/ rderlass_im_20051221_lernziele.pdf.

AG-F IV - LFV NRW, AGBF NRW, WFV NRW, \& IdF NRW (2007). Lernziele für die Ausbildung zum Zugführer (Freiwillige Feuerwehr) [Learning Objectives for Training of Platoon Leaders (Voluntary Fire Department)]. Retrieved from http://www.idf.nrw.de/ service/downloads/pdf/lernziele_zugfuehrer_20070925.pdf.

Bandura, A. (1977), Social learning theory, Prentice-Hall, Oxford, England.

Beywl, W. (Ed.). (2003). "Selected comments to the standards for evaluation of the German evaluation society - English edition - ", available at http://www.degeval.de/images/ stories/Publikationen/Selected_Comments_German_Evaluation_Standards_030409.pdf

Blanchard, P. N., and Thacker, J. W. (2010), Effective training: Systems, strategies, and practices (4th ed.), Pearson Education, Upper Saddle River, N.J..

Bliese, P. (2016), multilevel: Multilevel Functions. (Version 2.6) [Computer software], available at https://CRAN.R-project.org/package=multilevel

Cattell, R. B. (1966). The scree test for the number of factors. Multivariate behavioral research, 1(2), 245-276. DOI: 10.1207/s15327906mbr0102_10

Cohen, J. (1992), “A power primer”, Psychological Bulletin, Vol. 112, No. 1, pp. 155-159. 
Costello, A. B., and Osborne, J. W. (2005), "Best practices in exploratory factor analysis: Four recommendations for getting the most from your analysis", Practical Assessment, Research \& Education, Vol. 10, No. 7, pp. 1-9.

Epskamp, S. (2014), "semPlot: Unified visualizations of structural equation models", Structural Equation Modeling, Volume 22, No. 3, pp. 474-483.

Evers, A. (2001), “The revised Dutch rating system for test quality”, International Journal of Testing, Vol. 1, No, 2, pp. 155-182.

Feuerwehr-Dienstvorschrift (FwDV) 3: Einheiten im Lösch- und Hilfeleistungseinsatz [German fire service regulation 3: units in extinguishing and assistance incidents] (2008).

Gagne, P., and Hancock, G. R. (2006), "Measurement model quality, sample size, and solution propriety in confirmatory factor models", Multivariate Behavioral Research, Vol. 41, No. 1, pp. 65-83.

Ghedin, E., and Aquario, D. (2008), "Moving towards multidimensional evaluation of teaching in higher education: A study across four faculties", Higher Education, Vol. 56, No. 5, pp. 583-597.

Gläßer, E., Gollwitzer, M., Kranz, D., Meiniger, C., Schlotz, W., Schnell, T. and Voß, A. (2002), ,Trierer Inventar zur Lehrevaluation [Trier inventory of teaching evaluation; Measurement instrument]“, available at https://www.zpid.de/pub/tests/ PT_9004523_TRIL_weibl_Doz_Fragebogen.pdf

Hölbling, G. (2007). Handlungshilfen für Bildungsberater: Qualitätssicherung betrieblicher Weiterbildung [Guidance for eduactional consultants: quality management in vocational training]. Bielefeld, Germany: Bertelsmann.

Holling, H. (1999), “Evaluation eines komplexen Fortbildungsprogramms zur Steigerung der beruflichen Kompetenz [Evaluation of a complex profressional training for the enhancement of job skills]", in H. Holling and G. Gediga (Eds.), Evaluationsforschung [Evaluation research], Hogrefe, Göttingen, pp. 1-33.

Horn, J. L. (1965). A rationale and test for the number of factors in factor analysis. Psychometrika, 30(2), 179-185. DOI: 10.1007/BF02289447

IdF NRW [State Fire Service Institute North Rhine-Westphalia] (2012), IdF NRW Ausbildungsplan - Musterstundenplan B III 2012 [IdF NRW exemplary syllabus for group leaders in professional fire departments 2012], available at http://www.idf.nrw.de/ausbildung/katalog/dokumente/musterausbildungsplan_biii.pdf

IdF NRW [State Fire Service Institute North Rhine-Westphalia] (2013). IdF NRW Ausbildungsplan -Musterplan F III [IdF NRW exemplary syllabus for group leaders in voluntary fire departments], available at http://www.idf.nrw.de/ ausbildung/katalog/dokumente/musterausbildungsplan_fiii_26.pdf

Jäger, R. (2004), „Konstruktion einer Ratingskala mit Smilies als symbolische marken [Construction of a rating scale with smilies as symbolic labels]", Diagnostica, Vol. 50, No. 1, pp. 31-38. 
Kirkpatrick, D. L. (1979), “Techniques for evaluating training programs”, Training and Development Journal, Vol. 14, No. 6, pp. 78-92. Available at:

http://iptde.boisestate.edu/

FileDepository.nsf/bf25ab0f47ba5dd785256499006b15a4/693b43c6386707fc87257815 0059c1f3/\$FILE/Kirkpatrick_79.pdf

Kirkpatrick, D. L. (1998), Evaluating training programs - the four levels (2nd ed.). BerrettKoehler Publishers, San Francisco, CA.

Marsh, H. W. (1984), "Students' evaluations of university teaching: Dimensionality, reliability, validity, potential biases, and utility", Journal of Educational Psychology, Vol. 76, No. 5, pp. 707-754.

Marsh, H. W. (1987), "Students' evaluations of university teaching: Research findings, methodological issues, and directions for future research", International Journal of Educational Research, Vol. 11, No. 3, pp. 253-388.

Marsh, H. W., and Roche, L. A. (1997), "Making students' evaluations of teaching effectiveness effective: The critical issues of validity, bias, and utility", American Psychologist, Vol. 52, No. 11, pp. 1187-1197.

Mayring, P. (2000), “Qualitative content analysis”, Forum: Qualitative social research 1, Art. 20.

McDonald, R. P. (1999), Test theory: A unified treatment, Lawrence Erlbaum Associates, Mahwah, NJ.

Meyer, D., Dimitriadou, E., Kornik, K., Weingessel, A., and Leisch, F. (2015), „E1071: misc functions of the department of statistics, probability theory group (formerly: e1071)', TU Wien (Version 1.6-7) [Computer software], TU Wien, Vienna, Austria.

R Core Team. (2016), R: A language and environment for statistical computing (Version 3.3.2) [Computer software], R Foundation for Statistical Computing, Vienna, Austria.

Revelle, W. (2016), psych: Procedures for Personality and Psychological Research (Version 1.6.12) [Computer software], Northwestern University, Evanston, Il.

Rindermann, H. (2001). Lehrevaluation: Einführung und Überblick zu Forschung und Praxis der Lehrverantstaltungsevaluation an Hochschulen. mit einem Beitrag zur Evaluation computerbasierten Unterrichts (1st ed.), Empirische Pädagogik e.V, Landau.

Rindermann, H. and Schofield, N. (2001), „Generalizability of Multidimensional Student Ratings of University Instruction Across Courses and Teachers", Research in Higher Education, Vol. 42, No. 4, pp. 377-399.

Rosseel, Y. (2012), “Lavaan: An R package for structural equation modeling”, Journal of Statistical Software, Vol. 48, No. 2.

Schermelleh-Engel, K., Moosbrugger, H., and Müller, H. (2003), „Evaluating the fit of structural equation models: Tests of significance and descriptive goodness-of-fit measures", Methods of Psychological Research, Vol. 8, No. 2, pp. 23-74. Available at: https://www.dgps.de/ fachgruppen/methoden/mpr-online/issue20/art2/mpr130_13.pdf 
semTools Contributors (2016), semTools: Useful tools for structural equation modeling (Version 0.4-14) [Computer software], available at: https:/CRAN.Rproject.org/package $=$ semTools

Spiel, C. (2001), "Der differentielle Einfluß von Biasvariablen auf studentische Lehrveranstaltungsbewertungen [The differential influence of bias variables on students' course evaluations]", in U. Engel (Eds.), Hochschul-Ranking. Zur Qualitätsbewertung von Studium und Lehre [College rankings: on the quality appraisal of studying and teaching], Campus, Frankfurt am Main/New York, NY, pp. 61 -82.

Thielsch, M. T., Brinkmöller, B. \& Forthmann, B. (2018). Reasons for responding in student evaluation of teaching. Studies in Educational Evaluation, 56, 189-196. https://doi.org/10.1016/j.stueduc.2017.11.008

Viechtbauer, W. (2010), "Conducting meta-analyses in R with the metafor package", Journal of Statistical Software, Vol. 36, No. 3, pp. 1-48. 


\section{Evaluation of Firefighter Leadership Trainings}

Online Supplement 
Table A1

Categorization of Teaching Quality Aspects - Results from Study 1

\begin{tabular}{|c|c|c|c|}
\hline Category & Subcategory & $\begin{array}{l}\text { Number of } \\
\text { statements }\end{array}$ & $\begin{array}{l}\text { Percentage of } \\
\text { statements in } \\
\text { subcategory }\end{array}$ \\
\hline \multirow{6}{*}{$\begin{array}{l}\text { Main } \\
\text { characteristics of } \\
\text { good teaching } \\
\text { (330 statements) }\end{array}$} & Trainer & 160 & 49 \\
\hline & Trainee & 20 & 6 \\
\hline & Group & 35 & 11 \\
\hline & Context conditions & 87 & 26 \\
\hline & Teaching Success & 24 & 7 \\
\hline & Other & 4 & 1 \\
\hline \multirow{8}{*}{$\begin{array}{l}\text { Good trainer } \\
\text { (209 statements) }\end{array}$} & Personality \& social competence & 57 & 27 \\
\hline & Verbal expression \& comprehensibility & 21 & 10 \\
\hline & Competence \& experience & 47 & 23 \\
\hline & Structure \& clarity & 8 & 4 \\
\hline & Engagement \& motivation & 19 & 9 \\
\hline & Teaching competence & 35 & 17 \\
\hline & Interaction with class $\&$ feedback & 19 & 9 \\
\hline & Trainers team & 3 & 1 \\
\hline \multirow{8}{*}{$\begin{array}{l}\text { Good Trainee } \\
\text { (132 statements) }\end{array}$} & Preparation \& previous knowledge & 22 & 17 \\
\hline & Interest \& willingness to learn & 27 & 20 \\
\hline & Engagement & 37 & 28 \\
\hline & Discipline \& Respect & 14 & 11 \\
\hline & Postprocessing & 4 & 3 \\
\hline & Group cohesion & 21 & 16 \\
\hline & Ability to transfer learnings & 4 & 3 \\
\hline & Other & 3 & 2 \\
\hline \multirow{7}{*}{$\begin{array}{l}\text { Good context } \\
\text { conditions } \\
\text { (158 statements) }\end{array}$} & Accommodation & 34 & 21 \\
\hline & Pre-training information & 17 & 11 \\
\hline & (Time) schedule & 27 & 17 \\
\hline & $\begin{array}{l}\text { Participants/training (motivation, size, } \\
\text { etc.) }\end{array}$ & 17 & 11 \\
\hline & Trainer & 22 & 14 \\
\hline & Facilities and equipment & 36 & 23 \\
\hline & Course content/level of requirement & 5 & 3 \\
\hline \multirow{5}{*}{$\begin{array}{l}\text { Potential bias } \\
\text { variables } \\
\text { ( } 46 \text { statements) }\end{array}$} & Trainer & 13 & 28 \\
\hline & Trainees & 10 & 22 \\
\hline & Context conditions & 11 & 24 \\
\hline & External biases & 7 & 15 \\
\hline & Exam & 5 & 11 \\
\hline
\end{tabular}

Note. Content analysis was conducted by two independent and trained observers; observer agreement was $\kappa=0.85$ for main characteristics of good teaching, $\kappa=0.90$ for good trainer, $\kappa=0.88$ for good trainee, $\kappa=0.96$ for good context conditions, and $\kappa=0.86$ for potential bias variables. 
Table A2

Items Used in Study Two and Respective Reasons for Exclusion.

\begin{tabular}{|c|c|c|}
\hline \multicolumn{3}{|c|}{ Item } \\
\hline no. & Item & Reason for exclusion \\
\hline 1 & $\begin{array}{l}\text { Die Dozenten verhielten sich den Teilnehmern gegenüber } \\
\text { freundlich und respektvoll. [The trainers acted friendly and } \\
\text { respectful towards the participants.] }\end{array}$ & loading patterns \\
\hline 2 & $\begin{array}{l}\text { Die Dozenten hatten für die Belange der Teilnehmer ein } \\
\text { offenes Ohr. [The trainers had a sympathetic ear for the } \\
\text { participant's concerns.] }\end{array}$ & loading patterns \\
\hline 3 & $\begin{array}{l}\text { Ich finde, die Dozenten waren offen für Kritik. [I think, the } \\
\text { trainers had an open mind on criticism.] }\end{array}$ & loading patterns \\
\hline 4 & $\begin{array}{l}\text { Es herrschte eine gute Arbeitsatmosphäre. [The work climate } \\
\text { was good.] }\end{array}$ & loading patterns \\
\hline 5 & $\begin{array}{l}\text { Die Dozenten konnten adäquat auf die Fragen der Teilnehmer } \\
\text { antworten. [The trainers were able to answer the participant's } \\
\text { questions adequately.] }\end{array}$ & loading patterns \\
\hline 6 & $\begin{array}{l}\text { Ich finde, die Dozenten wirkten fachlich sehr kompetent. [I } \\
\text { think, the trainers appeared to be competent.] }\end{array}$ & $\begin{array}{l}\text { correlation of . } 76 \\
\text { with item } 7\end{array}$ \\
\hline 7 & $\begin{array}{l}\text { Die Dozenten kannten sich mit den Inhalten der Lehre sehr } \\
\text { gut aus. [The trainers were very familiar with the content of } \\
\text { their teaching.] }\end{array}$ & loading patterns \\
\hline 8 & $\begin{array}{l}\text { Die Dozenten konnten den Unterricht mit ihren eigenen } \\
\text { Einsatzerfahrungen gut ergänzen. [The trainers were able to } \\
\text { supplement the lessons with their own mission experience.] }\end{array}$ & loading patterns \\
\hline 9 & $\begin{array}{l}\text { Die Dozenten haben das Thema interessant aufgearbeitet. } \\
\text { [The trainers worked up the topic interestingly.] }\end{array}$ & loading patterns \\
\hline 10 & $\begin{array}{l}\text { Die Dozenten benutzten oft Beispiele, die zum Verständnis } \\
\text { der Lehrinhalte beitrugen. [The trainers often used examples } \\
\text { which contributed to the understanding of the course content.] }\end{array}$ & loading patterns \\
\hline 11 & $\begin{array}{l}\text { Die eingesetzten Lehrmethoden (z. B. Präsentation, } \\
\text { Gruppenarbeit) trugen zum Verständnis der Inhalte bei. [The } \\
\text { applied teaching methods (e.g. presentations, group work) } \\
\text { supported the understanding of the content.] }\end{array}$ & loading patterns \\
\hline 12 & $\begin{array}{l}\text { Ich finde, die theoretischen und praktischen Anteile standen in } \\
\text { einem angemessenen Verhältnis zueinander. [I think, theory } \\
\text { and practice were in an adequate proportion to one another.] }\end{array}$ & loading patterns \\
\hline 13 & $\begin{array}{l}\text { Es gab ausreichend Gelegenheiten, das Gelernte praktisch zu } \\
\text { erproben. [There were sufficient opportunities to put theory } \\
\text { into practice.] }\end{array}$ & loading patterns \\
\hline 14 & $\begin{array}{l}\text { Ich finde, die Lehrmethoden waren gut auf unsere } \\
\text { Teilnehmergruppe abgestimmt. [I think, the teaching methods } \\
\text { were well tailored to our group of participants.] }\end{array}$ & loading patterns \\
\hline
\end{tabular}


(continued)

15 Ich profitiere von „Aha-Erlebnissen“ durch sehr eindrückliche loading patterns

Übungen und Beispiele. [I was able to benefit from light bulb

moments after impressive exercises and examples.]

16 Der sprachliche Ausdruck der Dozenten war verständlich. dropped $\alpha$ value, $M$

[The trainer's oral expression was easy to understand.] $\quad=6.49$, very specific

content

17 Die Dozenten erläuterten Fachbegriffe ausreichend. [The loading patterns

trainers explained technical terms sufficiently.]

18 Die Dozenten fassten schwierige Sachverhalte prägnant

zusammen. [The trainers condensed difficult topics

concisely.]

19 Ich finde, die Dozenten gingen auf Fragen und Anregungen loading patterns

der Teilnehmer angemessen ein. [I think, the trainers

answered participant's questions and suggestions

appropriately.]

20 Ich finde, die Dozenten gaben nützliches Feedback. [I think, the trainers gave useful feedback.]

21 Ich finde, die Dozenten waren engagiert. [I think, the trainers loading patterns were well engaged in the course.]

22 Die Dozenten motivierten mich, mich einzubringen. [The trainers motivated me to participate actively in the course.]

23 Ich hatte den Eindruck, dass die Dozenten gut vorbereitet waren. [I think, the trainers were well prepaired.]

content: relevance, $M=6.47, S D=.73$

24 Ich finde, die Dozenten waren am Lernerfolg der Teilnehmer interessiert. [I think, the trainers were interested in the participants' learning success.]

25 Ich finde, die Lehrveranstaltung war klar strukturiert. [I think, the course was well-structured.]

26 Ich konnte im Verlauf der Lehrveranstaltung die Gliederung immer nachvollziehen. [I was always able to follow the structure of the course.]

27 Ich finde, die Lehrveranstaltung gab einen guten Überblick über das Themengebiet. [I think, the course gave a good overview of the subject area.]

28 Zu Beginn der Lehrveranstaltung wurden die Lernziele deutlich dargestellt. [At the beginning of the course, the learning objectives were presented clearly.]

29 Ich finde, die Dozenten teilten die zur Verfügung stehende Zeit gut ein. [I think, the trainers divided the available time well.] 
(continued)

30 Ich finde, die Dozenten waren gut aufeinander abgestimmt. [I correlation of .79 think, the trainers were well coordinated with each other.]

with item 32

31 Die Dozenten verfolgten ein einheitliches Lehrkonzept. [The correlation of .8 with trainers followed a consistent teaching concept.] item 32

32 Ich finde, die Dozenten haben ihr Vorgehen gut miteinander loading patterns abgestimmt. [I think, the trainers coordinated their line of action well.]

33 Der Umfang der zu lernenden Inhalte hat mich überfordert. [I was overexerted by the amount of subject matter.] (reversed coded)

34 Ich hätte mich mit einigen Themen gerne intensiver loading patterns beschäftigt. [I wish, I had been able to deal with some of the topics more intensively.] (reversed coded)

35 Das Tempo der Stoffvermittlung war zu hoch für mich. [The speed of impartation was too high.] (reversed coded)

36 Zentrale Inhalte wurden nicht wiederholt. [Critical course content was not repeated.] (reversed coded)

37 Die Inhalte der Lehrveranstaltung waren zu schwierig für mich. [The courses content was too difficult for me.] (reversed coded)

38 Die Dozenten passten die vermittelten Inhalte zu wenig an den Wissensstand der Teilnehmer an. [The trainers did not match the imparted content with the participants' knowledge.] (reversed coded)

39 Ich hatte zu wenige Vorkenntnisse, um der Lehrveranstaltung folgen zu können. [I had too little previous knowledge to follow the training.] (reversed coded)

40 Die Dozenten verdeutlichten die praktische Relevanz des Stoffes zu wenig. [The trainers did not point out the practical relevance of the subject matter enough.] (reversed coded)

41 Die anderen Teilnehmer brachten sich aktiv ein. [The other trainees participated actively.]

42 Die anderen Teilnehmer verfolgten den Lehrgang aufmerksam $\quad M \geq 6 \& S D \leq 1$ und mit Interesse. [The other participants followed the training attentively and with great interest.]

43 Die Teilnehmer unterstützen sich gegenseitig. [The participants supported each other.]

44 Ich finde, es herrsche ein guter Zusammenhalt im Lehrgang. [I think, there was a strong solidarity within the course.]

45 Ich habe in der Lehrveranstaltung sehr viel gelernt. [I learned $\quad M \geq 6 \& S D \leq 1$ a lot during the training.] 
(continued)

$46 \quad$ Ich konnte mein Wissen deutlich erweitern. [I was able to extend my knowledge significantly.]

correlation of .84

with item 45

47 Ich fühle mich auf meinen nächsten Einsatz, den ich als Gruppen-/Zugführer leiten werde, sehr gut vorbereitet. [I feel prepared for my next mission as a group/platoon leader.]

48 Durch die praktischen Übungen im Lehrgang habe ich die nötige Sicherheit gewonnen, einen Einsatz als Gruppen/Zugführer zu leiten. [By participating in the field trainings I gained the necessary self-assurance for leading a mission as a group/platoon leader.]

49 Ich kann das Gelernte auf meine Heimatstelle übertragen. [I can use the acquired knowledge on the job.]

50 Durch meine Teilnahme am Lehrgang gelingt es mir jetzt besser, Gefahrenlagen frühzeitig zu erkennen. [After this training, I can identify dangerous situations earlier.]

51 Durch meine Teilnahme am Lehrgang fällt es mir jetzt leichter, Entscheidungen in kritischen Situationen zu treffen. [After the training it is easier to make decisions in critical situations.]

52 Durch meine Teilnahme am Lehrgang kann ich meine eigene loading patterns Fähigkeit als Gruppen-/Zugführer besser einschätzen. [After this training I can judge my capabilities as a group/platoon leader better.]

53 Durch meine Teilnahme am Lehrgang kenne ich meine persönlichen Grenzen besser. [After this training, I know my personal limitations better than before.]

54 Durch meine Teilnahme am Lehrgang traue ich mir besser zu, in stressigen Situationen ruhig zu bleiben. [After this training, I think I am more capable of staying calm in stressful situations better.]

55 Durch meine Teilnahme am Lehrgang bin ich jetzt noch motivierter, die Rolle des GF/ZF zu übernehmen. [After this training, I am even more motivated to take on the role of a group/platoon leader.]

56 Durch meine Teilnahme am Lehrgang bin ich darin bestärkt, Führungsverantwortung zu übernehmen. [The training encouraged me to take managerial responsibility.]

loading patterns

Loadings and content: secondary loading of .22; managerial responsibility is assigned anyway

(continued) 
(continued)

57 Durch meine Teilnahme am Lehrgang habe ich ein besseres loadings and content:

Verständnis davon, welche Informationen meine Gruppe/mein difficult to assess via

Zug von mir benötigt. [After the training I have a better self-ratings understanding of what information my group/platoon needs.]

58 Durch meine Teilnahme am Lehrgang ist mir klarer loadings and content: geworden, was meine Gruppe/mein Zug von mir erwartet. similar to 57 and [Through the training it became clearer to me what my secondary loading of group/platoon expects.] .26

59 Durch meine Teilnahme am Lehrgang kann ich korrektere und verständlichere Anweisungen geben. [The training enabled me to give more specific and clearer assignments.]

60 Durch meine Teilnahme am Lehrgang sehe ich stärker die loadings and content: Sinnhaftigkeit von Einsatznachbesprechungen. [After the training I perceive debriefings as more reasonable.]

61 Durch meine Teilnahme am Lehrgang werde ich very specific Einsatznachbesprechungen erfolgreich leiten können. [The training enabled me to conduct debriefings.]

62 Ich kann meine Arbeit jetzt besser planen und koordinieren. [I loading patterns can now plan and coordinate my work better.]

63 Ich kann meine Entscheidungen jetzt besser durchsetzen. [I loading patterns can now assert my decisions better.]

64 Ich beherrsche den Führungsvorgang jetzt besser. [Now I can handle the leadership process better.]

correlation of .83 with item 65

65 Ich beherrsche wichtige Führungstechniken jetzt besser. [I $\quad M \geq 6 \& S D \leq 1$ now know how to use important leadership techniques better.]

Note. Dashes in the last column indicated that the item was included in the final questionnaire. 
Table A3

Factor Loadings and Discriminatory Power for Exploratory Factory Analysis with Varimax Rotation of Process Items

\begin{tabular}{|c|c|c|c|c|c|c|c|c|}
\hline Item & $\begin{array}{l}\text { Trainer's } \\
\text { behavior }\end{array}$ & $\begin{array}{c}\text { Over- } \\
\text { extension }\end{array}$ & Structure & Group & Mean & SD & $\begin{array}{l}\text { Discri- } \\
\text { minatory } \\
\text { power }\end{array}$ & $\begin{array}{c}\alpha \text { if } \\
\text { dropped }\end{array}$ \\
\hline Item 16 & .74 & & & & 6.49 & 0.59 & .61 & .83 \\
\hline Item $18^{*}$ & .73 & & & & 6.07 & 0.82 & .69 & .80 \\
\hline Item $20^{*}$ & .72 & & & & 6.33 & 0.87 & .71 & .80 \\
\hline Item $24^{*}$ & .71 & & & .32 & 6.54 & 0.73 & .67 & .81 \\
\hline Item $22^{*}$ & .70 & & & & 6.22 & 0.84 & .62 & .83 \\
\hline Item 21 & .65 & & .35 & & 6.69 & 0.52 & & \\
\hline Item 5 & .64 & & .33 & & 6.24 & 0.85 & & \\
\hline Item 7 & .62 & & .40 & & 6.53 & 0.64 & & \\
\hline Item 8 & .62 & & .29 & & 6.28 & 0.96 & & \\
\hline Item 17 & .62 & .31 & & & 6.25 & 0.75 & & \\
\hline Item 2 & .60 & & & .33 & 6.23 & 0.76 & & \\
\hline Item 19 & .58 & & & .31 & 6.27 & 0.85 & & \\
\hline Item 32 & .57 & & & & 5.77 & 1.24 & & \\
\hline Item 1 & .57 & & & .40 & 6.62 & 0.65 & & \\
\hline Item 10 & .57 & & .48 & & 6.37 & 0.79 & & \\
\hline Item 3 & .56 & & & & 6.05 & 0.97 & & \\
\hline Item 4 & .53 & & & .31 & 6.40 & 0.68 & & \\
\hline Item 29 & .39 & & .30 & .39 & 6.10 & 0.94 & & \\
\hline Item $35^{*}$ & & .86 & & & 5.22 & 1.43 & .78 & .82 \\
\hline Item $37^{*}$ & & .83 & & & 5.88 & 1.10 & .78 & .83 \\
\hline Item $33^{*}$ & & .82 & & & 5.12 & 1.45 & .72 & .85 \\
\hline Item 39 & & .79 & & & 5.80 & 1.20 & .69 & .86 \\
\hline Item 38 & & .66 & & & 5.53 & 1.23 & & \\
\hline Item 36 & & .57 & & & 5.10 & 1.54 & & \\
\hline Item 13 & & .52 & & .43 & 4.93 & 1.65 & & \\
\hline Item 40 & & .48 & & & 5.89 & 1.06 & & \\
\hline Item 34 & & .46 & & & 3.08 & 1.37 & & \\
\hline Item 12 & & .44 & & .33 & 5.68 & 1.26 & & \\
\hline
\end{tabular}

Note. Table shows only loadings $>.3$. Factor loadings $>.40$ are in boldface. Selected items are marked with an asterisk $(*)$. Discriminatory power is the part-whole corrected itemtotal correlation (i.e. the item's correlation with the sum of all other items of this item's scale). Alpha if dropped shows the reliability (Cronbach's raw $\alpha$ ) of the corresponding scale, if the item is dropped from the scale on which the highest factor loading is found.

(continued) 
Table A3 (continued)

\begin{tabular}{lcccccccc}
\hline & $\begin{array}{c}\text { Trainer's } \\
\text { behavior }\end{array}$ & $\begin{array}{c}\text { Over- } \\
\text { extension }\end{array}$ & Structure & Group & Mean & SD & $\begin{array}{c}\text { Discri- } \\
\text { minatory } \\
\text { power }\end{array}$ & $\begin{array}{c}\alpha \text { if } \\
\text { dropped }\end{array}$ \\
\hline Item 26* & & & .69 & & 5.73 & 0.95 & .68 & .75 \\
Item 25* & & .30 & .68 & & 6.00 & 0.85 & .68 & .75 \\
Item 27* & & & .68 & & 5.90 & 0.88 & .69 & .76 \\
Item 28 & & & .62 & .32 & 5.70 & 1.17 & .56 & .83 \\
Item 9 & .51 & .60 & & 6.31 & 0.77 & & \\
Item 11 & .43 & .57 & & 5.93 & 1.02 & & \\
Item 14 & .34 & & .50 & .30 & 5.57 & 1.09 & & \\
Item 43* & & & & .79 & 6.40 & 0.69 & .69 & .51 \\
Item 44* & & & & .68 & 6.60 & 0.66 & .53 & .70 \\
Item 41* & & .32 & & .63 & 5.93 & 0.76 & .50 & .74 \\
Item 15 & & & .40 & 6.12 & 0.93 & & \\
\hline
\end{tabular}

Note. Table shows only loadings $>.3$. Factor loadings $>.40$ are in boldface. Selected items are marked with an asterisk $(*)$. Discriminatory power is the part-whole corrected itemtotal correlation (i.e. the item's correlation with the sum of all other items of this item's scale). Alpha if dropped shows the reliability (Cronbach's raw $\alpha$ ) of the corresponding scale, if the item is dropped from the scale on which the highest factor loading is found. 
Table A4

Factor Loadings and Discriminatory Power for Exploratory Factory Analysis with Varimax Rotation of Outcome Items

\begin{tabular}{lcccccc}
\hline & $\begin{array}{c}\text { Compe- } \\
\text { tence }\end{array}$ & Transfer & Mean & SD & $\begin{array}{c}\text { Discri- } \\
\text { minatory } \\
\text { power }\end{array}$ & $\begin{array}{c}\alpha \text { if } \\
\text { dropp } \\
\text { ed }\end{array}$ \\
\hline Item 56 & .80 & & 5.97 & 0.97 & .73 & .91 \\
Item 59* & .79 & & 5.88 & 0.88 & .73 & .91 \\
Item 57 & .77 & & 6.17 & 0.79 & .72 & .91 \\
Item 58 & .73 & & 6.09 & 0.86 & .71 & .91 \\
Item 54* & .72 & & 5.49 & 1.00 & .68 & .91 \\
Item 51* & .70 & & 5.76 & 0.90 & .69 & .91 \\
Item 60 & .68 & & 6.02 & 1.02 & .62 & .91 \\
Item 53* & .66 & & 5.60 & 1.10 & .60 & .91 \\
Item 50* & .65 & .36 & 5.84 & 0.86 & .67 & .91 \\
Item 55 & .60 & .34 & 5.88 & 0.98 & .60 & .91 \\
Item 52 & .60 & .51 & 5.81 & 0.85 & .70 & .91 \\
Item 61 & .51 & .38 & 5.63 & 1.04 & .55 & .92 \\
Item 49* & & .82 & 5.73 & 1.12 & .69 & .78 \\
Item 48* & & .79 & 5.52 & 1.17 & .58 & .81 \\
Item 47* & & .78 & 5.57 & 1.08 & .64 & .79 \\
Item 62 & .43 & .67 & 5.92 & 0.81 & .66 & .80 \\
Item 63 & .51 & .59 & 5.64 & 1.03 & .61 & .80 \\
\hline
\end{tabular}

Note. Table shows only loadings $>.3$. Factor loadings $>.40$ are in boldface. Selected items are marked with an asterisk (*). Discriminatory power is the part-whole corrected item-total correlation (i.e. the item's correlation with the sum of all other items of this item's scale). Alpha if dropped shows the reliability (Cronbach's raw $\alpha$ ) of the corresponding scale, if the item is dropped from the scale on which the highest factor loading is found. 
Table A5

Final FIRE Items in German and English

\begin{tabular}{|c|c|c|c|}
\hline $\begin{array}{l}\text { Item } \\
\text { no. }\end{array}$ & $\begin{array}{l}\text { Dimen- } \\
\text { sion }\end{array}$ & Item in German & Item in English \\
\hline 18. & trainer & $\begin{array}{l}\text { Die Dozenten fassten } \\
\text { schwierige Sachverhalte } \\
\text { prägnant zusammen. }\end{array}$ & $\begin{array}{l}\text { The trainers condensed } \\
\text { difficult topics concisely. }\end{array}$ \\
\hline 20 & trainer & $\begin{array}{l}\text { Ich finde, die Dozenten gaben } \\
\text { nützliches Feedback. }\end{array}$ & $\begin{array}{l}\text { I think the trainers gave useful } \\
\text { feedback. }\end{array}$ \\
\hline 22 & trainer & $\begin{array}{l}\text { Die Dozenten motivierten } \\
\text { mich, mich einzubringen. }\end{array}$ & $\begin{array}{l}\text { The trainers motivated me to } \\
\text { participate actively in the } \\
\text { course. }\end{array}$ \\
\hline 24. & trainer & $\begin{array}{l}\text { Ich finde, die Dozenten waren } \\
\text { am Lernerfolg der } \\
\text { Teilnehmer interessiert. }\end{array}$ & $\begin{array}{l}\text { I think the trainers were } \\
\text { interested in the learning } \\
\text { success of the participants. }\end{array}$ \\
\hline 33. & $\begin{array}{l}\text { over- } \\
\text { extension }\end{array}$ & $\begin{array}{l}\text { Der Umfang der zu lernenden } \\
\text { Inhalte hat mich überfordert. } \\
\text { (reversed) }\end{array}$ & $\begin{array}{l}\text { I was overexerted by the } \\
\text { amount of subject matter. } \\
\text { (reversed) }\end{array}$ \\
\hline 35. & $\begin{array}{l}\text { over- } \\
\text { extension }\end{array}$ & $\begin{array}{l}\text { Das Tempo der } \\
\text { Stoffvermittlung war zu hoch } \\
\text { für mich. (reversed) }\end{array}$ & $\begin{array}{l}\text { The speed of impartation was } \\
\text { too high. (reversed) }\end{array}$ \\
\hline 37. & $\begin{array}{l}\text { over- } \\
\text { extension }\end{array}$ & $\begin{array}{l}\text { Die Inhalte der } \\
\text { Lehrveranstaltung waren } \mathrm{zu} \\
\text { schwierig für mich. } \\
\text { (reversed) }\end{array}$ & $\begin{array}{l}\text { The course content was too } \\
\text { difficult to me. (reversed) }\end{array}$ \\
\hline 25 & structure & $\begin{array}{l}\text { Ich finde, die } \\
\text { Lehrveranstaltung war klar } \\
\text { strukturiert. }\end{array}$ & $\begin{array}{l}\text { I think the course was well- } \\
\text { structured. }\end{array}$ \\
\hline 26. & structure & $\begin{array}{l}\text { Ich konnte im Verlauf der } \\
\text { Lehrveranstaltung die } \\
\text { Gliederung immer } \\
\text { nachvollziehen. }\end{array}$ & $\begin{array}{l}\text { I was always able to follow the } \\
\text { structure of the course. }\end{array}$ \\
\hline 27. & structure & $\begin{array}{l}\text { Ich finde, die } \\
\text { Lehrveranstaltung gab einen } \\
\text { guten Überblick über das } \\
\text { Themengebiet. }\end{array}$ & $\begin{array}{l}\text { I think the course gave a good } \\
\text { overview of the subject area. }\end{array}$ \\
\hline 41. & group & $\begin{array}{l}\text { Die anderen Teilnehmer } \\
\text { brachten sich aktiv ein. }\end{array}$ & $\begin{array}{l}\text { The other trainees participated } \\
\text { actively. }\end{array}$ \\
\hline 43. & group & $\begin{array}{l}\text { Die Teilnehmer unterstützen } \\
\text { sich gegenseitig. }\end{array}$ & $\begin{array}{l}\text { The participants supported } \\
\text { each other. }\end{array}$ \\
\hline 44. & group & $\begin{array}{l}\text { Ich finde, es herrsche ein } \\
\text { guter Zusammenhalt im } \\
\text { Lehrgang. }\end{array}$ & $\begin{array}{l}\text { I think there was a strong } \\
\text { cohesion within the course. }\end{array}$ \\
\hline 50 & $\begin{array}{l}\text { compe- } \\
\text { tence }\end{array}$ & $\begin{array}{l}\text { Durch meine Teilnahme am } \\
\text { Lehrgang gelingt es mir jetzt } \\
\text { besser, Gefahrenlagen } \\
\text { frühzeitig zu erkennen. }\end{array}$ & $\begin{array}{l}\text { After this training, I can } \\
\text { identify dangerous situations } \\
\text { earlier. }\end{array}$ \\
\hline
\end{tabular}

(continued) 
(continued)

\begin{tabular}{|c|c|c|c|}
\hline 51. & $\begin{array}{l}\text { compe- } \\
\text { tence }\end{array}$ & $\begin{array}{l}\text { Durch meine Teilnahme am } \\
\text { Lehrgang fällt es mir jetzt } \\
\text { leichter, Entscheidungen in } \\
\text { kritischen Situationen zu } \\
\text { treffen. }\end{array}$ & $\begin{array}{l}\text { After the training, it is easier to } \\
\text { make decisions in critical } \\
\text { situations. }\end{array}$ \\
\hline 53. & $\begin{array}{l}\text { compe- } \\
\text { tence }\end{array}$ & $\begin{array}{l}\text { Durch meine Teilnahme am } \\
\text { Lehrgang kenne ich meine } \\
\text { persönlichen Grenzen besser. }\end{array}$ & $\begin{array}{l}\text { After this training, I know my } \\
\text { personal limitations better than } \\
\text { before. }\end{array}$ \\
\hline 54. & $\begin{array}{l}\text { compe- } \\
\text { tence }\end{array}$ & $\begin{array}{l}\text { Durch meine Teilnahme am } \\
\text { Lehrgang traue ich mir besser } \\
\text { zu, in stressigen Situationen } \\
\text { ruhig zu bleiben. }\end{array}$ & $\begin{array}{l}\text { After this training, I dare to } \\
\text { keep calm in stressful } \\
\text { situations better. }\end{array}$ \\
\hline 59. & $\begin{array}{l}\text { compe- } \\
\text { tence }\end{array}$ & $\begin{array}{l}\text { Durch meine Teilnahme am } \\
\text { Lehrgang kann ich korrektere } \\
\text { und verständlichere } \\
\text { Anweisungen geben. }\end{array}$ & $\begin{array}{l}\text { The training enabled me to } \\
\text { give more specific and clearer } \\
\text { assignments. }\end{array}$ \\
\hline 47 & transfer & $\begin{array}{l}\text { Ich fühle mich auf meinen } \\
\text { nächsten Einsatz, den ich } \\
\text { leiten werde, sehr gut } \\
\text { vorbereitet. }\end{array}$ & $\begin{array}{l}\text { I feel prepared very well for } \\
\text { my next mission as a leader. }\end{array}$ \\
\hline 48. & transfer & $\begin{array}{l}\text { Durch die praktischen } \\
\text { Übungen im Lehrgang habe } \\
\text { ich die nötige Sicherheit } \\
\text { gewonnen, einen Einsatz zu } \\
\text { leiten. }\end{array}$ & $\begin{array}{l}\text { By participating in the field } \\
\text { trainings, I gained the } \\
\text { necessary self-assurance for } \\
\text { leading a mission. }\end{array}$ \\
\hline 49 & transfer & $\begin{array}{l}\text { Ich kann das Gelernte auf } \\
\text { meine Heimatstelle } \\
\text { übertragen. }\end{array}$ & $\begin{array}{l}\text { I can use the acquired } \\
\text { knowledge on the job. }\end{array}$ \\
\hline
\end{tabular}

Note. Trainer $=$ Trainers' behavior, competence $=$ competence acquisition. 


\section{FIRE: Feedback Instrument for Rescue Forces Education}

\section{Dear trainee}

Thank you for participating in our short survey. By rating several aspects of this training, you will help to evaluate the program's quality and support the identification of areas of further improvement. Please tick the answer which describes your degree of agreement to the following statements best. There are no right or wrong answers in this questionnaire. We are interested in your personal opinion.

Please note:

- Tick only one box after each statement

- Do not skip a statement

- If you cannot rate one statement, use the unanswerable option

\section{How far do you agree with the following statements?}

1. The trainers condensed difficult topics concisely.

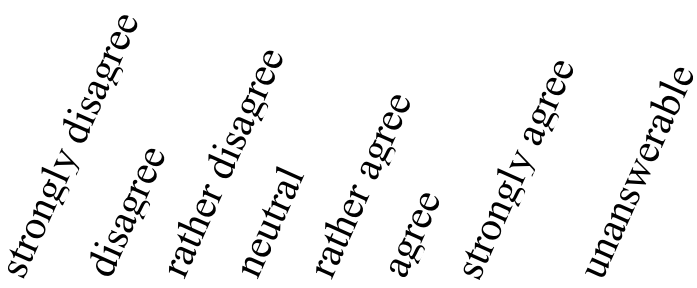

2. I think the trainers gave useful feedback.

3. The trainers motivated me to participate actively in the course.

4. I think the trainers were interested in the participants' learning success.

5. I was overexerted by the amount of subject matter.

6. The speed of impartation was too high.

7. The course content was too difficult for me.

8. I think the course was well-structured.

9. I was always able to follow the structure of the course.
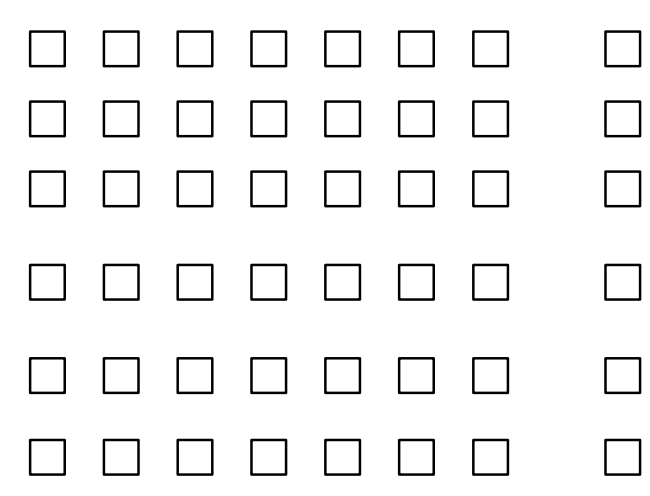

10. I think the course gave a good overview of the subject area.

11. The other trainees participated actively.

12. The participants supported each other.

13. I think there was a strong solidarity within the course.

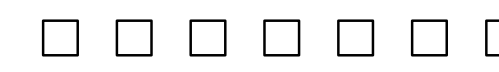


17. After this training, I think I am more capable of staying calm in stressful situations better.

18. The training enabled me to give more specific and clearer assignments.

19. I feel prepared very well for my next mission as a leader.

20. By participating in the field trainings, I gained the necessary self-assurance for leading a mission.

21. I can use the acquired knowledge on the job.
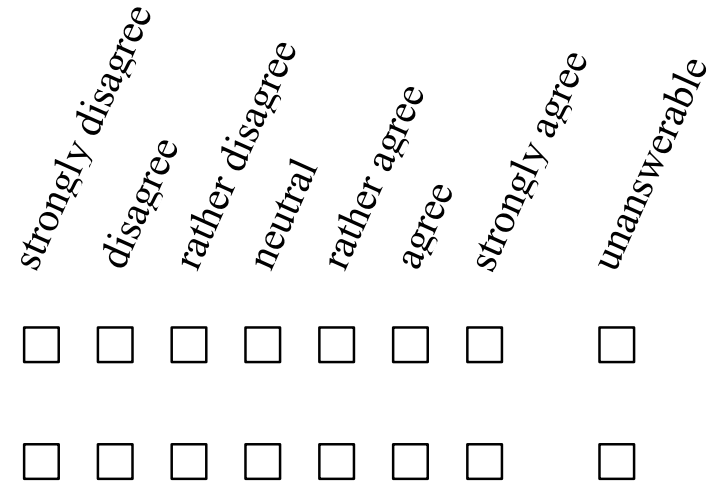

$\square \square \square \square \square \square \square$
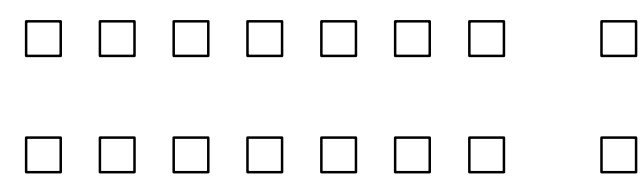


\section{FIRE: Feedback-Instrument zur Rettungskräfte-Entwicklung}

Liebe/r Lehrgangsteilnehmer/in,

wir schätzen es sehr, dass Sie an unserer Befragung teilnehmen. Indem Sie den Lehrgang hinsichtlich verschiedener Aspekte bewerten, helfen Sie uns, die Qualität der Lehre zu beurteilen und gegebenenfalls zu verbessern. Bitte kreuzen Sie hierzu bei jeder der folgenden Aussagen das Kästchen an, das den Grad Ihrer Zustimmung am besten beschreibt. Es gibt bei dieser Befragung keine richtigen oder falschen Antworten. Vielmehr interessieren wir uns für Ihre ganz persönliche Meinung.

Bitte beachten Sie:

- machen Sie hinter jeder Aussage jeweils nur ein Kreuz in einem der dafür vorgesehenen Kästchen (und niemals zwischen oder neben den Kästchen)

- bitte lassen Sie keine Aussagen aus

- wenn eine Aussage für Sie nicht sinnvoll beantwortbar ist, können Sie uns dies durch ein Kreuz in dem entsprechenden Kästchen mitteilen

- Aus Gründen der besseren Lesbarkeit wird an einigen Stellen nur die männliche Form (Dozent/Teilnehmer) verwendet. Die weibliche Form ist dabei jeweils miteingeschlossen.

\section{Bitte teilen Sie uns hierzu bei den folgenden Aussagen mit, wie sehr Sie diesen}

1. Die Dozenten fassten schwierige Sachverhalte prägnant zusammen.

2. Ich finde, die Dozenten gaben nützliches Feedback.

3. Die Dozenten motivierten mich, mich einzubringen.

4. Ich finde, die Dozenten waren am Lernerfolg der Teilnehmer interessiert.

5. Der Umfang der zu lernenden Inhalte hat mich überfordert.

6. Das Tempo der Stoffvermittlung war zu hoch für mich.

7. Die Inhalte der Lehrveranstaltung waren zu schwierig für mich.

8. Ich finde, die Lehrveranstaltung war klar strukturiert.

9. Ich konnte im Verlauf der Lehrveranstaltung die Gliederung immer nachvollziehen.

10. Ich finde, die Lehrveranstaltung gab einen guten Überblick über das
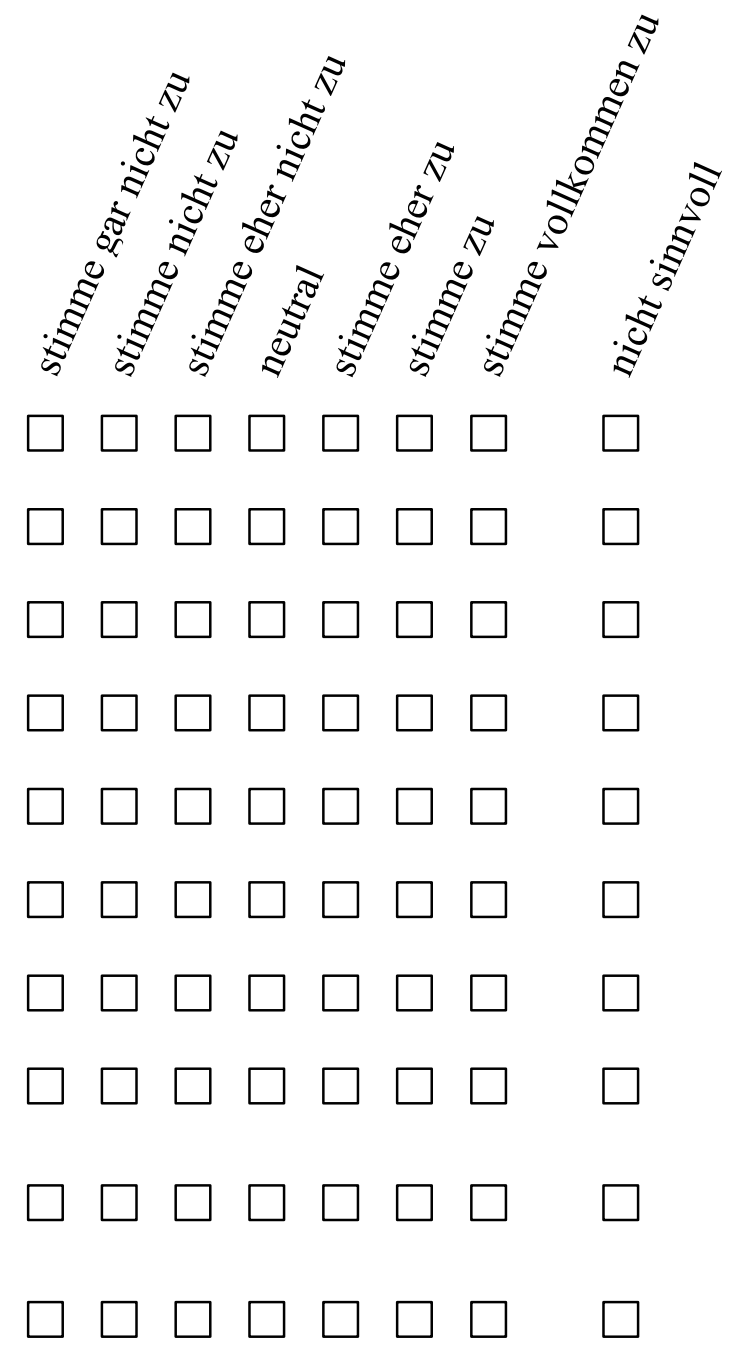
Themengebiet.

11. Die anderen Teilnehmer brachten sich aktiv ein.

12. Die Teilnehmer unterstützen sich gegenseitig.

13. Ich finde, es herrschte ein guter Zusammenhalt im Lehrgang.

14. Durch meine Teilnahme am Lehrgang gelingt es mir jetzt besser, Gefahrenlagen frühzeitig zu erkennen.

15. Durch meine Teilnahme am Lehrgang fällt es mir jetzt leichter, Entscheidungen in kritischen Situationen zu treffen.

16. Durch meine Teilnahme am Lehrgang kenne ich meine persönlichen Grenzen besser.

17. Durch meine Teilnahme am Lehrgang traue ich mir besser zu, in stressigen Situationen ruhig zu bleiben.

18. Durch meine Teilnahme am Lehrgang kann ich korrektere und verständlichere Anweisungen geben.

19. Ich fühle mich auf meinen nächsten Einsatz, den ich leiten werde, sehr gut vorbereitet.

20. Durch die praktischen Übungen im Lehrgang habe ich die nötige Sicherheit gewonnen, einen Einsatz zu leiten.

21. Ich kann das Gelernte auf meine Heimatstelle übertragen.
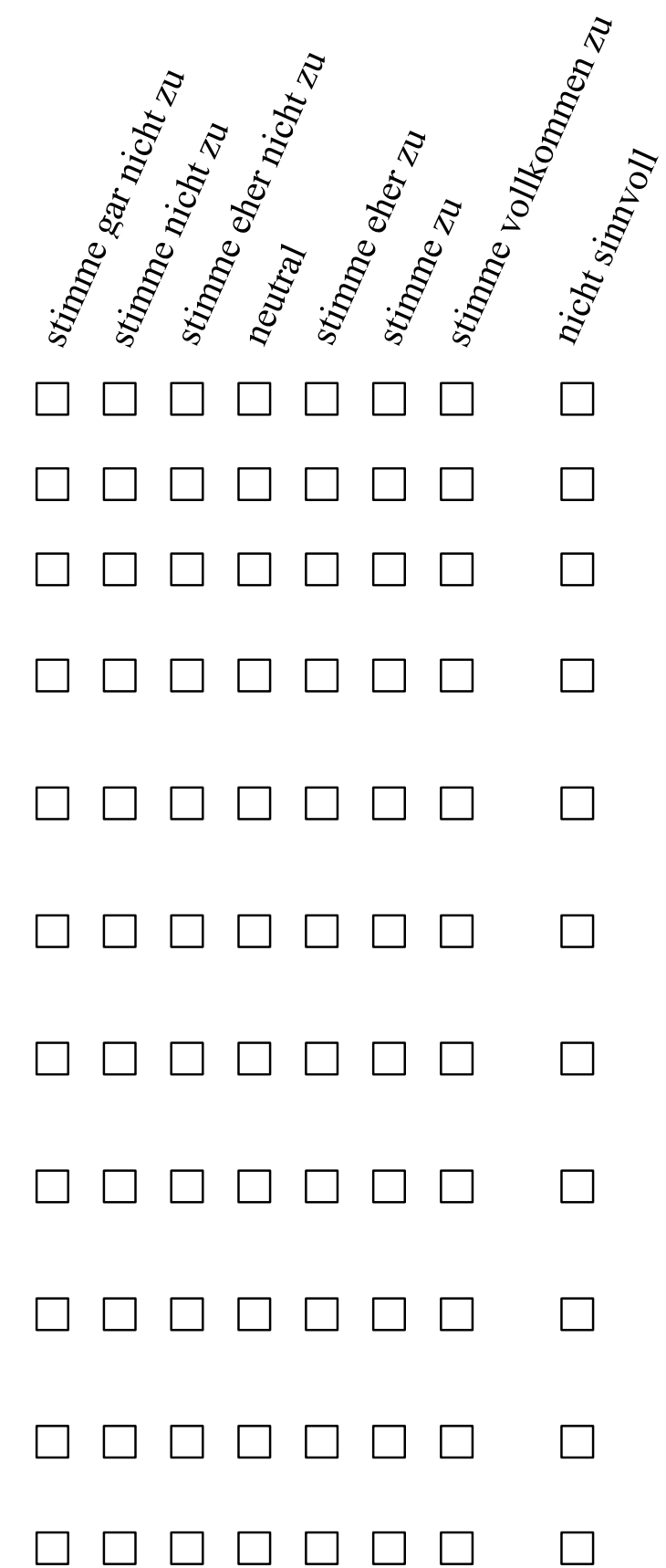


\section{FIRE Scoring Instructions}

\section{Step 1: Assign points to individual item responses}

For each question 1 point is given for the answer "strongly disagree", 2 points for "disagree", 3 points for "rather disagree", 4 points for "neutral", 5 points for "rather agree", 6 points for "agree", and 7 points for "strongly agree". If coded this way, high values on overextension indicate highly overextended trainees and therefore poor course performance. We recommend reversed coding for this scale (1 point for "strongly agree", 2 points for "agree", [...], 7 points for "strongly disagree". If "unanswerable" is checked, this item will be ignored for this person.

\section{Step 2: Aggregate item scores on course level}

Calculate the mean score per item by adding up all individual points for this item and then dividing this sum by the number of trainees who responded to this item. Keep in mind that the number of respondents is not necessary equal to the number of trainees in the course as some might have checked the unanswerable option. You end up with 21 means. It is important to state that these means should not be interpreted for evaluation purposes as the reliability of these single item measures can be assumed to be too low to meet psychometric standards.

\section{Step 3: Calculate scores for the six FIRE factors}

In a last step, the FIRE factor scores are determined. To obtain the core for a specific factor, add up all means (from step 2) of items measuring this specific scale and divide it by the number of items in this scale. See the following table for details.

Table A6

Factor score calculation

\section{Item numbers $\quad$ Factor score calculation of this scale}
a) Trainers' behavior
$1,2,3,4$

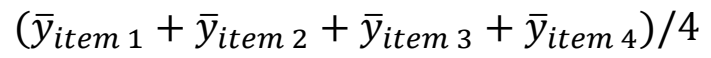
b) Overextension
$5,6,7$
$\left(\bar{y}_{i t e m ~} 5+\bar{y}_{\text {item } 6}+\bar{y}_{\text {item } 7}\right) / 3$
c) Structure
$8,9,10$
$\left(\bar{y}_{\text {item } 8}+\bar{y}_{\text {item } 9}+\bar{y}_{\text {item } 10}\right) / 3$
d) Group
$11,12,13$
$\left(\bar{y}_{\text {item } 11}+\bar{y}_{\text {item 12 }}+\bar{y}_{\text {item 13 }}\right) / 3$
e) Competence acquisition
$14,15,16,17,18$
$\left(\bar{y}_{\text {item } 14}+\bar{y}_{\text {item } 15}+\bar{y}_{\text {item } 16}+\bar{y}_{\text {item } 17}\right.$ $\left.+\bar{y}_{\text {item } 18}\right) / 5$
f) Transfer
$19,20,21$
$\left(\bar{y}_{\text {item } 19}+\bar{y}_{\text {item 20 }}+\bar{y}_{\text {item 21 }}\right) / 3$

Note. Numbers indicate question numbers; $\bar{y}$ denotes the mean item score obtained in step 2; order of questions is identical in English and German version. 


\section{Detailed Description of Study 3 Measures}

Scales corresponding to individual FIRE scales. The following scales served as convergent criterions for specific FIRE scales.

Trainer behavior. One of the best validated German evaluation instruments are HILVE scales. Here we used teaching competence (three items, $\alpha=.78$ ) and the adapted teacher's support subscales (two items, $r=.35$; both from HILVE I, Rindermann, 2001) to validate the corresponding FIRE scale. A sample item was "The trainers seem to be well prepaired".

Structure. Another well-established German-language teaching evaluation scale is the TRIL (Gläßer et al., 2002). Its structure subscale (six items, $\alpha=.86$ ) served as a convergent measure for the identically named FIRE scale. A sample item was "The learning objectives were clear and comprehensible".

Overextension. This FIRE scale was validated with the same-named HILVE I subscale (Rindermann, 2001; four items, $\alpha=.57$ ). A sample item was "I can still deal with the amount of subject matter".

Group. As the group of trainees is less relevant in other teaching contexts, available evaluation inventories did not offer an adequate scale. Therefore, we asked for group related behaviors with three self-developed items ("How many evenings of the course did you spend with other trainees at a restaurant?", "On how many evenings of the course did you spend at least two hours sitting together?", and "I would attend another course with the other trainees anytime again.", $\alpha=.57)$. For the first two items of the scale we used different anchors $(1=a t$ no evening and $7=$ at every available evening).

Competence. For this scale, the qualitative (two items, $\alpha=.71, r=.56$ ) and quantitative learning (two items, $\alpha=.71, r=.56$ ) subscales of HILVE II (Rindermann, 2009) were used. A sample item was "In this training I learn a lot."

Overall satisfaction. A group of five items measured the trainees' satisfaction with the course. Four of which were regular Likert items (e.g., "All in all, participating in this training was worthwhile."; TRIL; Gläßer et al., 2002). One item asked participants to rate the course on a six-point scale according to the German school grade rating system $(1=$ excellent, $6=$ failing). 


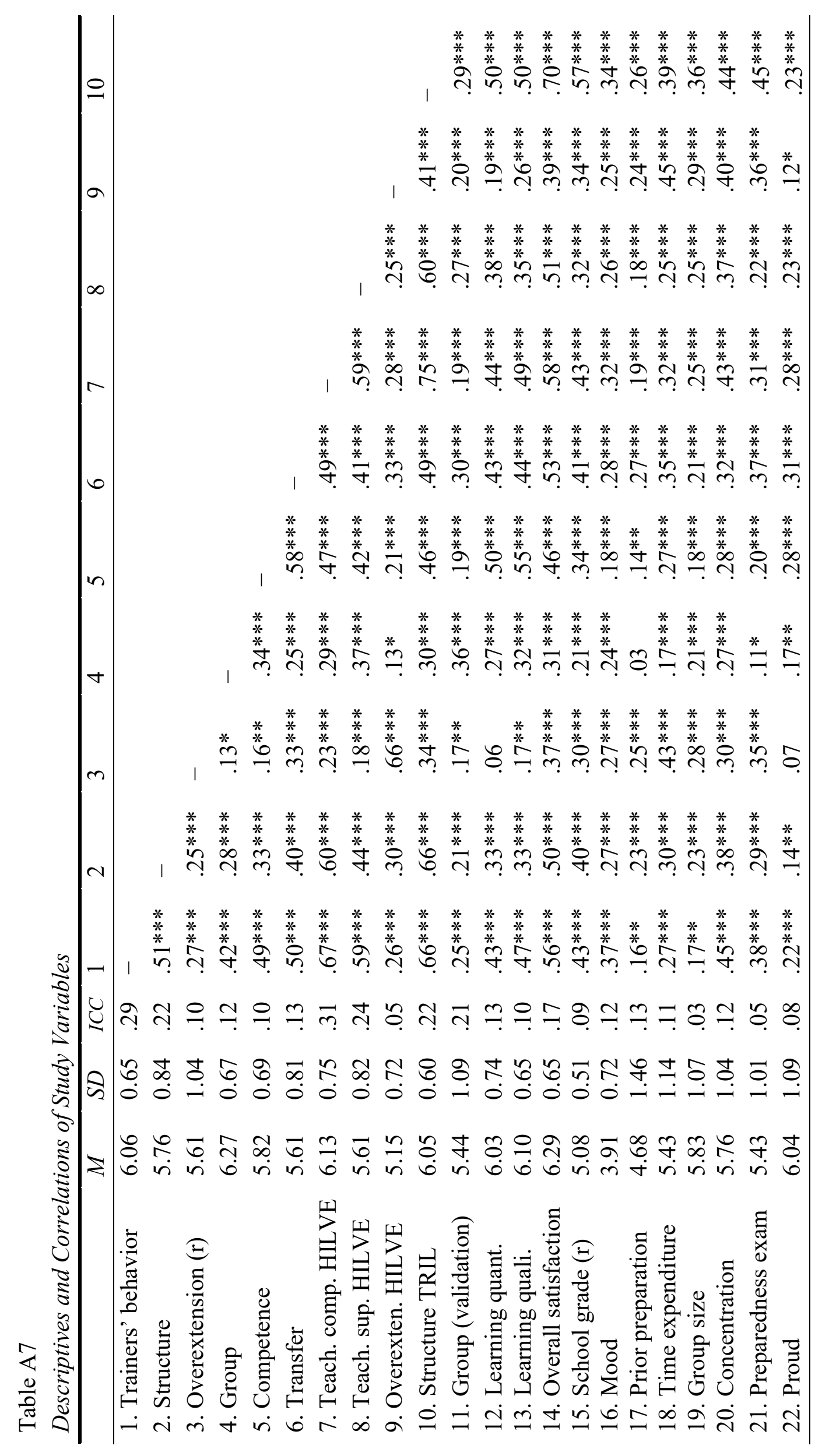




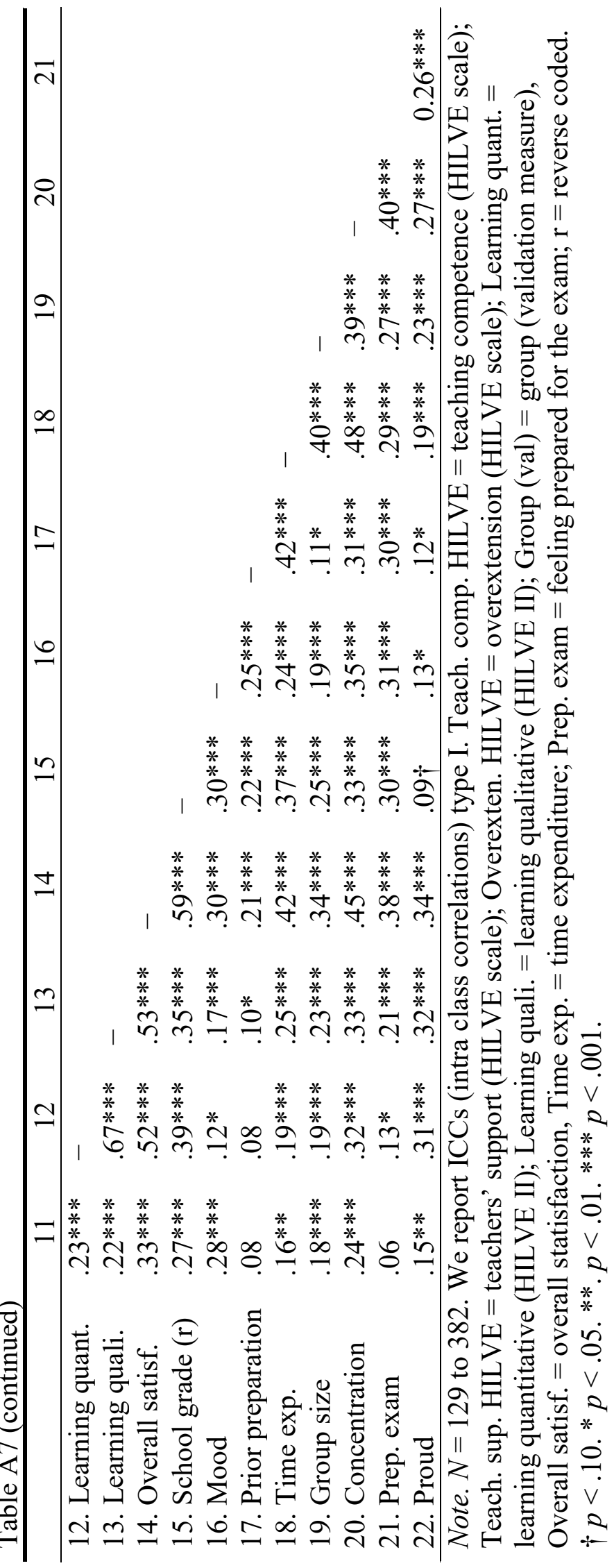


Table A8

Evaluation results (FIRE Scale)

\begin{tabular}{lcc}
\hline \multicolumn{1}{c}{ Scale } & Mean & SD \\
\hline Trainer's behavior & 6.15 & .66 \\
Structure & 5.80 & .82 \\
Overextension & 5.53 & 1.10 \\
Group & 6.29 & .64 \\
Competence & 5.78 & .72 \\
Transfer & 5.61 & .86 \\
\hline
\end{tabular}

Note. Results are based on the combined data of study 2 and 3. $N=621-625 . \mathrm{SD}=$ standard deviation.

Table A9

Results for agreement between trainers and trainees (Hedges'g) for each FIRE scale

\begin{tabular}{lccccc}
\hline \multirow{2}{*}{ FIRE subscale } & \multicolumn{5}{c}{ Estimated effect } \\
\cline { 2 - 6 } & $\hat{\theta}$ & $95 \% \mathrm{CI}$ & $\tau^{2}$ & $z$ & $p$ \\
\hline Trainers' behavior & $-.14(.22)$ & {$[-.57, .29]$} & $.30(.28)$ & -0.64 & .52 \\
Structure & $-.46(.24)$ & {$[-.93, .01]$} & $.47(.34)$ & -1.93 & .05 \\
Overextension & $-.91(.17)$ & {$[-1.25,-.58]$} & $.00(.17)$ & -5.33 & $<.0001^{* * *}$ \\
Group & $-.62(.33)$ & {$[-1.26, .02]$} & $1.22(.62)$ & -1.91 & .06 \\
Competence & $-.63(.21)$ & {$[-1.04,-.22]$} & $.24(.25)$ & -3.01 & $.003^{* *}$ \\
Transfer & $-.66(.23)$ & {$[-1.11,-.22]$} & $.35(.29)$ & -2.95 & $.003^{* *}$
\end{tabular}

Note. $\mathrm{k}=16$, standard errors in parentheses. $\hat{\theta}=$ estimate of Hedges'g, $\mathrm{CI}=$ confidence interval for the estimate of $\hat{\theta} . * p<.05 . * * . p<.01 . * * * p<.001$. 